\title{
AS RELAÇÕES ENTRE O MODELO DE GESTÃO E O DESENVOLVIMENTO SOCIOECONÔMICO DE UMA COOPERATIVA DE MEL: UM ESTUDO DE CASO NA COOPAPI EM APODI - RN.
}

\author{
Elisabete Christina Mendes Machado \\ Graduada em Tecnologia em Comércio Exterior pelo Instituto Federal de Educação, \\ Ciência e Tecnologia do Rio Grande do Norte - IFRN. E-mail: \\ elisabetemm@yahoo.com.br. \\ Denise Cássia da Silva
}

\section{RESUMO}

Esta pesquisa teve como objetivo analisar a existência da relação entre o modelo de gestão cooperativista e o desenvolvimento socioeconômico em uma cooperativa de mel (COOPAPI), na região do Semi-Árido em Apodi, no estado do Rio Grande do Norte. A fim de alcançar os objetivos proposto foi realizado um estudo de caso com enfoque metodológico baseado em uma pesquisa quantitativa, utilizando-se a técnica do questionário estruturado composto por setenta e quatro afirmativas aplicado a direção da cooperativa. Os aspectos mais importantes de diferenciação presentes na entrevista referem-se: a gestão da cooperativa e quais os aspectos que mais interferem para o seu desenvolvimento sócio e econômico. Como aporte teórico para analisar o modelo de gestão adotou-se diversos autores, dentre eles podemos destacar: Paul Singer, Djalma de Pinho Rebouças de Oliveira, Airton Cardoso Cançado. No que tange ao cooperativismo, foi utilizado o embasamento teórico dos seguintes autores: Maria Luiza Lins Pires, Sandra Mayrink Veiga, Jose Abrantes entre outros. Os resultados obtidos mostraram que, mesmo diante de um ambiente com várias dificuldades de gestão, técnicas e econômicas, a cooperativa consegue se expandir tornando-se um exemplo a ser seguido, por toda a região. Acima de tudo mantendo sempre a sua essência, ou seja, a cooperação.

PALAVRAS-CHAVE: Gestão Cooperativista. Cooperativa de Mel. COOPAPI.

\begin{abstract}
This research has a objective analyze the existence of relation between the cooperative management model with socioeconomic develop in a honey company cooperative (COOPAPI), in semi-arid on Apodi, in a Rio Grande do Norte state. With objective of reach the propose objectives was a case study research with a methodological focus base in a quantitative research, use the questionnaire technique composed for sixty-four questions apply for board of directors of cooperative. The aspects more important of distinction in the interview it's about: The management of cooperative and which aspects that more interfere for the develop socio and economic. Like theoretical contribute for analyze the management model was base in miscellaneous authors, between their: Paul Singer, Djalma de Pinho Rebouças de Oliveira, Airton Cardoso Cançado. In the ambit cooperative, was used the theoretical emplacement of some authors: Maria Luiza Lins Pires, Sandra Mayrink Veiga, Jose Abrantes etc. the results shows that, even in front of a ambient with many management, technical an economics
\end{abstract}


distressed, the cooperative reach develop, become a example to be follower, for region. Above all always keep it's gist, that's mean cooperation.

KEY-WORDS: Cooperative Management. Honey's Cooperative. COOPAPI. 


\section{AS RELAÇÕES ENTRE O MODELO DE GESTÃO E O DESENVOLVIMENTO SOCIOECONÔMICO DE UMA COOPERATIVA DE MEL: UM ESTUDO DE CASO NA COOPAPI EM APODI - RN.}

\section{INTRODUÇÃO}

A gestão empresarial é um ponto fundamental para o desenvolvimento de uma empresa, e com o processo de globalização é algo em constante mudança na atualidade, devido à rapidez como tudo ocorre, o empresário deverá andar passo a passo em sintonia com o mundo, não mais com uma visão retrograda, fechada, ou seja, de restrita decisão própria. Hoje esse gestor deverá optar por tomadas de decisões em conjunto com o meio em que trabalha, ou seja, junto aos seus colaboradores, um novo modelo de gerir sua organização, uma gestão cada vez mais participativa, onde todos poderão contribuir com idéias inovadoras, se tornando uma comunidade cada vez mais competitiva para enfrentar a vasta concorrência existente no mundo.

Devido a essas novas exigências globais, as sociedades cooperativistas vêm evoluindo ao longo dos anos e tornando-se cada vez mais competitivas dentro da economia mundial, as cooperativas inserem-se no contexto do regime de mercado em que atuam e se deparam com os mesmos desafios e problemas que afetam as empresas, ou seja, as semelhanças entre essas organizações e as sociedades de capital residem no conjunto de necessidades de recursos para garantir sua sobrevivência e sua expansão.

Antes o principal enfoque do cooperado era vender tudo que poderia produzir, hoje devido às novas exigências globais, ele tende a se adaptar e produzir apenas o que o mercado demanda, se quiser realmente competir com as grandes empresas, essa nova visão requer tomadas de decisões rápidas e decisivas, daí a importância da colaboração de todos os cooperados. De forma geral o crescimento das estruturas cooperativas é seguido pelo aumento da complexidade de sua gestão, típica das grandes corporações.

Diante desse cenário o Rio Grande do Norte não poderia se mostrar diferente, ou seja, o aumento da força cooperativista vem crescendo e desenvolvendo um ótimo trabalho no interior do estado, mais precisamente no município de Apodi, como é o caso da Cooperativa Potiguar de Apicultura (COOPAPI) que vem desenvolvendo um excelente trabalho com relação ao aumento na produção de mel e inovando em diversos setores da agricultura familiar, como: a castanha de caju, doce, a polpa de fruta, o algodão orgânico entre outros produtos. Esse trabalho vem tendo destacado, por ter uma gestão inovadora, que conta com o apoio de todo o corpo da cooperativa.

De forma geral o setor apicultor do estado do Rio Grande do Norte tem se mostrado em plena ascensão para o desenvolvimento socioeconômico do estado, gerando emprego e renda para os pequenos produtores. (ASSESSORIA E COMUNICAÇÃO, 2009).

Segundo Pereira et al (2002) A apicultura é uma das atividades capazes de causar impactos positivos, tanto sociais, ambientais quanto econômicos, além de contribuir para manutenção e preservação dos ecossistemas existentes. A cadeia produtiva da apicultura propicia a geração de inúmeros postos de trabalho, emprego e fluxo de renda, principalmente no ambiente familiar, sendo, dessa forma, determinante na melhoria da 
qualidade de vida, preservação do meio ambiente, melhoria de renda familiar e fixação do homem no meio rural.

O desafio das estruturas cooperativas modernas é manter seu papel de sistema produtivo centrado no homem e, ao mesmo tempo, desenvolver organização capaz de competir com empresas de outras naturezas com orientação para o mercado.

Assim estudar a gestão das organizações cooperativistas e como estas assegura a sua dimensão econômica e social se faz relevante, principalmente para as cooperativas do Nordeste Brasileiro, que passam por um processo de revitalização, a começar por sua gestão que deve ser participativa e competitiva para perpetuar no mercado e garantir a viabilidade econômica.

Objetivo geral desse trabalho é a constituição de referenciais no âmbito da gestão cooperativista, para analisar o desenvolvimento sócio e econômico de uma cooperativa de mel no estado do Rio Grande do Norte, um setor que tem se mostrado cada vez mais promissor no estado, tendo em vista as constantes dificuldades encontradas pelas cooperativas na área de gestão. E verificar de que forma a participação dos cooperados contribui para melhoria e evolução dessa associação.

Já os objetivos específicos do trabalho estão organizados em: a) estudar conceitos e identificar na prática como a gestão interfere nas organizações cooperativistas, ajudando o desenvolvimento socioeconômico; b) verificar o desenvolvimento da cooperativa de apicultura que será estudada e que contribuições que esta concede ao estado do RN; c) identificar a participação nas exportações de mel pela cooperativa no estado no Rio Grande do Norte; d) analisar a capacidade da cooperativa em compatibilizar as demandas sociais e econômicas da atualidade; e) Investigar, no exercício da prática diária, o cumprimento dos valores e princípios do cooperativismo, através das alianças mantidas entre os sócios e do seu nível de participação na cooperativa.

A metodologia aplicada neste trabalho consiste na busca e pesquisa exploratória descritiva por meio de consultas a livros, artigos e revistas. Também será realizado levantamento de dados secundários utilizando a exemplo de web sites.

Segundo Vergara (2007), a pesquisa descritiva expõe características de determinada população ou determinado fenômeno. Pode também estabelecer correlações entre variáveis e definir sua natureza. Não tem compromisso de explicar fenômenos que descreve, embora sirva de base para tal explicação. Pesquisa de opinião insere-se nessa classificação.

Também foi realizada a leitura de algumas monografias, artigos científicos, revistas especializadas e teses sobre o assunto. Segundo Gil (2002), a pesquisa bibliográfica desenvolvida com base em materiais prontos, constituídos principalmente de livros, artigos científicos e periódicos, podendo a pesquisa de um trabalho ser exclusivamente por meio de fontes bibliográficas.

A fim de alcançar os objetivos propostos, foi realizado um estudo de caso na COOPAPI- Cooperativa de Apicultores situada em Apodi interior do estado do Rio Grande do Norte. Onde feito realizado uma entrevista quantitativa estruturada, aplicada a gestão da cooperativada, mais especificamente a presidente da mesma. 
Segundo Vergara (2007), estudo de caso é o circunscrito a uma ou poucas unidades, entendidas essas como pessoa, família, produto, empresa órgão publico, comunidade ou mesmo país. Tem caráter de profundidade e detalhamento. Pode ou não ser realizada no campo.

A escolha do tema gestão cooperativista abordado neste trabalho justifica-se por ser assunto pouco explorado na visão do Comércio Exterior e há ainda uma carência significativa de trabalhos acadêmicos na área, sejam monografias, artigos científicos dentre outro, assunto esse de extrema relevância não só para um desenvolvimento social, como também econômico do estado do Rio Grande do Norte.

Vale ressalta que, em determinados períodos do curso a pesquisadora já havia trabalhado com outros projetos direcionados a médias e grandes empresas, despertando à curiosidade e o interesse do setor cooperativista, pelo fato desse setor estar em plena ascensão no estado. Outro fator determinante na escolha desse tema se deu por meio da inquietação feita por leituras em jornais e revistas locais que, deixa claro o significante aumento nas exportações da apicultura no estado potiguar, onde o setor apicultor no estado vem se desenvolvendo, por ser uma atividade de grande alcance social devido ao baixo custo de implementação e manutenção, sem contar que por ser um produto saudável e natural, houve um significativo aumento no consumo, não apenas nas mesas brasileira, como também pelos mercados estrangeiro, adaptando-se as exigências impostas pelos grandes compradores, daí o seu significativo desenvolvimento.

O estudo consiste também em contribuição no setor acadêmico, pois pretende identificar os fatores pelo qual vem se observando a evolução do setor apícola e explorar os pontos fortes da gestão cooperativista, procurando contribuir de alguma forma para melhorias no setor, ou seja, uma cooperativa organizada e bem gerida tem maiores condições de agregar valor ao produto final, organizar sua produção e conquistar não só mercado interno mais atingir o mercado internacional, tendo condições de competir com grandes empresas exportadoras.

$\mathrm{Na}$ visão de Oliveira (2006), os principais problemas identificados na gestão das cooperativas são a falta ou o esquecimento da educação cooperativista; a falta de cooperação entre as cooperativas; a aplicação de modelos de gestão centralizados, inadequados e desatualizados.

O trabalho encontra-se estruturado nas seguintes partes: o primeiro capítulo esclarece e define conceitos referentes ao cooperativismo, demonstrado como surgiu essa doutrina, como se deu sua inserção no Brasil, quis foram as primeiras cidades brasileiras a adotarem essa doutrina e como se deu o seu desenvolvimento no nordeste. Ainda no primeiro capítulo iremos demonstrar como as cooperativas estão divididas e classificadas, a importância da cooperativa agropecuária e a evolução no setor das exportações.

No segundo capítulo será abordada a questão da economia solidaria no Brasil, seus seguidores e adeptos, a defesa dos princípios autogestionários, a questão da dependência heterogestionária ainda muito forte no país. Em seguida discorrerá a gestão cooperativista mostrando as dificuldades enfrentadas, as vantagens de se ter esse embasamento para que ocorra um desenvolvimento das organizações e as estratégias 
que deverá ser adotada pelas cooperativas possam concorrer com os outros tipos de organização.

O terceiro capítulo tratará do estudo de caso, fazendo menção no primeiro momento a importância da apicultura e o desenvolvimento no estado, em seguida pretende mostrar a relação entre o aposto teórico estudado, ou seja, se o modelo de gestão cooperativista se identifica com o adotado pela cooperativa. Para isso, foi realizado um questionário estruturado em cinco etapas que abrange questões relativas aos aspectos institucionais, técnicos, atividades produtivas agrícolas, organizacionais e de gestão e por último aos aspectos econômicos.

\section{COOPERATIVISMO}

Existem vários significados a respeito da palavra cooperativa, para que possamos compreender melhor o contexto desse trabalho é necessário explicitar alguns pontos como: seu significado, onde surgiu, como foi inserido no Brasil e principalmente no nordeste, principal foco desse trabalho.

Segundo Pinho (1966), embora etimologicamente cooperação, cooperativa e cooperativismo derivem do verbo cooperar, de origem latina cooperari (cum e operari) que significa trabalhar com alguém, são conceitos distintos. Enquanto a cooperação significa ação conjunta com vista ao mesmo objetivo, o cooperativismo, por sua vez, significa sistema, doutrina ou ideologia e, finalmente, a cooperativa seria uma entidade ou instituição onde as pessoas cooperam objetivando o mesmo fim.

A Aliança Cooperativista Internacional (2004) define cooperativa como sendo uma associação autônoma de pessoas que se unem, voluntariamente, para satisfazer aspirações e necessidades econômicas, sociais e culturais comuns, por meio de uma empresa de propriedade comum e democraticamente gerida. (CAÇADO, 2007).

De acordo com a Organização das Cooperativas do Brasil (2003), Órgão representante do cooperativismo no Brasil conforme a Lei 5764/71, define que as cooperativas são associações autônomas de pessoas que se unem voluntariamente para satisfazer aspirações e necessidades econômicas, sociais e culturais comuns, por meio de uma empresa de propriedade coletiva e democraticamente gerida. Elas se baseiam em valores de ajuda mútua e responsabilidade, democracia, igualdade, eqüidade e solidariedade e, seus princípios históricos e suas características legais, têm como um de seus aspectos marcantes a forma como a gestão dos seus negócios é realizada.

O cooperativismo teve forte influência das idéias socialistas, ou seja, visando associação entre as pessoas e pregando a igualdade entre os homens. Um dos principais objetivos era descentralizar a gestão e fazer com que, a opinião de todos os membros fosse primordial para o desenvolvimento econômico e social da corporação.

Cooperativismo no sentido de doutrina que tem por objeto a correção do social pelo econômico através de associações de fim predominantemente econômico, ou seja, as cooperativas; cooperativas no sentido de sociedades de pessoas organizadas em bases democráticas, que visam não só a suprir seus membros de bens e serviços como também a realizar determinados programas educativos e sociais. Trata-se, insistimos de sociedade de pessoas e não de capital, sem interesse lucrativo e com fins econômicos- sociais. Seu funcionamento se inspira nos chamados "Princípios dos Pioneiros de 
Rochdale": adesão livre, gestão democrática, juros módicos ao capital, retorno proporcional às operações, transações a dinheiro, neutralidade política, religiosa e ética e desenvolvimento do ensino. (PINHO, 1966, p.8).

A Organização Internacional do Trabalho, na Recomendação $\mathrm{N}^{\circ} 193^{1}$, traça o conceito geral de cooperativa definindo cooperativa como uma associação autônoma de pessoas que se unem voluntariamente para satisfazer suas necessidades e aspirações econômicas, sociais e culturais por meio de uma sociedade de propriedade comum e de gestão democrática.

Apesar de diversas instituições estabeleceram um conceito para as cooperativas, elas se divergem na compreensão de uma organização democrática capaz de satisfazer as aspirações econômicas. No Brasil ainda não há um consenso estabelecido com relação à unicidade da Organização das Cooperativas do Brasil (OCB), como representante do cooperativismo, assim como algumas categorias que lutam pela pluralidade da representatividade das cooperativas, como é o caso dos agricultores familiares que estão vinculados a União Nacional das Cooperativas de Agricultura Familiar e Economia Solidária (UNICAFES), ou seja, alguns autores divergem a respeito do conceito de igualdade e gestão democrática igualitária, conforme podemos observar:

Existem dois tipos de cooperativa a autentica que é socialista, igualitária, solidária e democrática, onde a igualdade faz sentido e, de outro lado, cooperativas de visão essencialmente capitalistas, como as agrícolas onde grandes fazendeiros exploram pequenos proprietários. Uma parte dos trabalhadores destas cooperativas, porém, são funcionários e não cooperados. (SINGER, 2000 apud CANÇADO, 2007, p.52).

De acordo com Singer (2000), esta situação acontece para que possa haver demissão quando se fizer necessário, pelas regras do mercado capitalista, ou seja, para se preservar a eficiência do complexo cooperativo, existe uma população flutuante de funcionários contratados passiveis de demissão, quando necessário.

No que tange a União Nacional das Cooperativas de Agricultura Familiar e Economia Solidária (UNICAFES), podemos considerar que é uma organização que visa promover e buscar políticas e condições socioeconômicas favoráveis ao cooperativismo agropecuário inserido na chamada economia solidária. Uma entidade não governamental que propõe a inclusão social dos cooperados articulando iniciativas econômicas, que ampliem as oportunidades de trabalho, de distribuição de renda, de produção de alimentos, das melhorias de qualidade de vida, da preservação da biodiversidade e da diminuição das desigualdades.

Dentre outras especificidades essa organização visa o desenvolvimento socioeconômico dos seus empreendimentos, não só nos princípios que prega, mas dentro da realidade de cada comunidade, fazendo com que o trabalho seja reconhecido de maneira cada vez mais satisfatória. Maximizando as oportunidades no maior número possível de desenvolvimento humano em todas as regiões do território brasileiro.

\footnotetext{
${ }^{1}$ Recomendação 193 é a recomendação sobre a Promoção de Cooperativas, adotada pela Conferência internacional do trabalho em sua $90^{\circ}$ Reunião, realizada em Genebra em 20 de junho e 2002.
} 


\section{CONTEXTO HISTÓRICO DO COOPERATIVISMO}

A mais antiga cooperativa documentada data de 1760, sendo compostas por trabalhadores dos estaleiros de Woolwich e Chatam, na Inglaterra. Criada com o objetivo de moer os cereais dos associados, reduzindo os custos cobrados pelos moleiros estabelecidos (ABRANTES, 2004).

A seguir o exemplo da Inglaterra outros países como Escócia, Alemanha e França tentaram adotar o conceito cooperativista, alguns até obtiveram êxito, já outros idealista não obtiveram resultados positivos com as experiências de cooperação compartilhadas, sendo que, a maioria das literaturas referente ao cooperativismo registra como marco histórico os Pioneiros de Rochdale, que segundo (SINGER, 1998 apud ABRANTES, 2004) a cidade de Manchester era um dos piores exemplos das mazelas sociais e nela imperava a miséria. Em novembro de 1843, pressionados pelo desemprego e sob a influência das idéias de Robert Owen $^{2}, 28$ tecelões (27 homens e uma mulher), do subúrbio de Rochdale, com o apoio de George Jacob Holyoake ${ }^{3}$, reuniram-se e decidiram economizar uma libra cada um, durante um ano, para formar uma associação de consumo. A sociedade foi registrada oficialmente em 24 de outubro de 1844 com o nome Friendly Society, e o armazém teve as portas abertas pouco mais de um mês depois, tendo apenas pequenas quantidades de farinha, manteiga, aveia e açúcar. Somente em 1852 assumiria oficialmente o nome Rochadale Society of Equitable Pioneers Limeted. O movimento cooperativista se expandiu e permanece na atualidade como alternativa de geração de trabalho e renda.

Segundo Silva Filho (2001), o sucesso de "Rochdale" inspirou o movimento cooperativista pelo mundo, de tal modo que os valores (solidariedade, igualdade, fraternidade, democracia, equidade, responsabilidade social, transparência) e os princípios (adesão livre e voluntária, controle democrático pelos sócios, participação econômica dos sócios, autonomia e independência, educação, treinamento e informação, cooperação entre cooperativas, preocupação com a comunidade) elaborados pelos "Probos Pioneiros" são, até hoje, com algumas reformulações feitas pela Aliança Cooperativista Internacional (ACI), adotados pelo movimento cooperativista.

De uma forma bastante explicita os princípios de Rochadale orientam as entidades cooperativista, para que essas conservem seus valores, melhorando o desenvolvimento socioeconômico, não só dos cooperados, como também de toda a comunidade envolvida, diante desse contexto a organização internacional do trabalho (193) aponta que, os princípios cooperativos são diretrizes através das quais as cooperativas põem em prática seus valores e as cooperativas trabalham para o desenvolvimento sustentável de suas comunidades por meio de políticas aprovadas por seus membros.

\footnotetext{
${ }^{2}$ Robert Owen socialista pré-marxista é apontado como um dos mais importantes idealistas da filosofia cooperativista, sendo considerado o pai do cooperativismo inglês. Ver Luz Filho (1961).

${ }^{3}$ George Jacob Holyoake era um socialista cristão e teve forte influência na criação da cooperativa de Rockdale em 1844; foi também um dos fundadores da Aliança Cooperativa Internacional- ACI. Figueiredo (2000).
} 


\section{COOPERATIVISMO NO BRASIL}

No Brasil, a cultura da cooperação é observada desde a época da colonização portuguesa. Esse processo emergiu no movimento cooperativista Brasileiro surgido no final do século XIX, estimulado por funcionários públicos, militares, profissionais liberais e operários, para atender às suas necessidades. O movimento iniciou-se na área urbana, com a criação da primeira cooperativa de consumo de que se tem registro no Brasil, em Ouro Preto (MG), no ano de 1889, denominada Sociedade Cooperativa Econômica dos Funcionários Públicos de Ouro Preto. (ORGANIZAÇÃO DAS COOPERATIVAS DO BRASIL, 2008).

Registros mais exatos data do ano de 1902 como sendo o marco do cooperativismo no Brasil, ou seja, para (BULGARELLI, 2000 Apud CARRADORE, 2005) apesar de algumas tentativas anteriores, pode-se fixar o início do movimento cooperativo no Brasil, em 1902, com a fundação da primeira caixa rural Raiffeisen, no Rio Grande do Sul, em Nova Petrópolis, graças aos esforços do padre suíço Theodor. Amsteadt, datando também dessa época, a criação da caixa rural de Goiânia, em Pernambuco, que, contudo, não sobreviveu; e simultaneamente na Bahia.

Há de se ressalta que, no que se diz respeito ao aspecto legal perante a lei, só alguns anos mais tarde foi formalizado a doutrina cooperativista brasileira, segundo Polônio (2004) o decreto 22.239, de 19-12-1932. Este sim, visto como o estatuto do cooperativismo pode ser considerado o marco da formalização legal da atividade no Brasil.

Independente da data seja ela 1902, ou 1932, ou até mesmo registros anteriores, podemos afirmar que, a inserção do cooperativismo no Brasil veio para modificar o pensamento de uma sociedade individualista capitalista para o movimento mais humanista, ainda que seja a passos lentos, até os dias de hoje.

Entretanto (PINHO, 1982 apud SILVA NETO et al 2000), o cooperativismo no Brasil foi por duas grandes tendências: o predomínio do pensamento doutrinário Rochdaleano, com início no final do século XIX, tendo durado aproximadamente 80 anos; e a partir do início da década de 1970, a tentativa de combinar a promoção da atividade humana solidária a racionalidade empresarial, deixando de ser idealista para se firmar na economia de mercado como cooperativa-empresa.

Tendo em vista vários aspectos de inserção do cooperativismo no Brasil e no mundo, foram criados alguns órgãos de identificação para que essas entidades possam lutar por um maior reconhecimento e mais destaque na sociedade. $O$ maior órgão de representatividade das cooperativas é a Aliança Cooperativista Internacional (ACI) inserida em 108 países contendo 800 mil cooperativas e 810 milhões de cooperados. No Brasil o órgão máximo de representação das cooperativas é a Organização das Cooperativas Brasileiras (OCB), foi criada em 1969, durante o IV Congresso Brasileiro de Cooperativismo. A entidade veio substituir a Associação Brasileira de Cooperativas (ABCOOP) e a União Nacional de Cooperativas (Unasco). A unificação foi uma decisão das próprias cooperativas. Já a nível estadual as cooperativas são representadas pelas organizações das cooperativas estaduais (OCES). (OCB, 2008). 
Para que possamos entender melhor o sistema cooperativista, a organização das cooperativas brasileiras estabeleceu 13 ramos diferentes, baseados de acordo com o objeto ou pela natureza das atividades desenvolvidas pelas cooperativas ou por seus associados, são eles: Agropecuário, Consumo, Crédito, Educacional, Especial, Habitacional, Infra-estrutura, Mineral, Produção, Saúde, Trabalho, Transporte, Turismo e Lazer, como mostra a tabela a seguir.

A ilustração a seguir demonstra o último senso feito pela organização das cooperativas brasileiras, destacando a quantidade de cooperativas existentes no Brasil, o número de associados e conseqüentemente o número de empregados viventes em cada uma delas.

\begin{tabular}{|l|l|l|l|}
\hline Ramo de atividade & Cooperativas & Associados & Empregados \\
\hline Agropecuário & 1.611 & 968.767 & 134.579 \\
\hline Consumo & 138 & 2.316 .036 & 8.813 \\
\hline Crédito & 1.113 & 3.215 .866 & 38.796 \\
\hline Educacional & 327 & 57.331 & 2.980 \\
\hline Especial & 15 & 531 & 10 \\
\hline Habitacional & 340 & 78.983 & 1.354 \\
\hline Infra-estrutura & 148 & 623.431 & 5.664 \\
\hline Mineral & 53 & 19.975 & 105 \\
\hline Produção & 215 & 11.931 & 2.442 \\
\hline Saúde & 894 & 215.755 & 47.132 \\
\hline Trabalho & 1.746 & 287.241 & 4.997 \\
\hline Transporte & 1.060 & 90.744 & 7.640 \\
\hline Turismo e Lazer & 22 & 1.116 & 44 \\
\hline Totais & 7.682 & 7.887 .707 & 254.256 \\
\hline
\end{tabular}

Ilustração 1: Número de cooperativas por ramos

Fonte: Unidades Estaduais e OCB; Base: Dez/2008; Elaboração: Gemerc/OCB

Segundo a Organização das Cooperativas Brasileiras (2008) no Brasil hoje existem 7.682 cooperativas contendo 7.887 .707 associados e 254.556 empregados sendo subdivididos por região da seguinte forma: as maiores concentrações de cooperativas se encontram nas regiões Sul e Sudeste que se mantiveram na liderança do faturamento bruto do cooperativismo. Paraná, Minas Gerais, São Paulo, Rio Grande do Sul e Santa Catarina concentraram a maior fatia desse crescimento. As regiões Nordeste e CentroOeste vêm em seguida com o aumento de $21,52 \%$ e $18,8 \%$, respectivamente.

\section{MARCO DO COOPERATIVISMO NO NORDESTE}

O marco histórico no caso do cooperativismo nordestino está associado ao setor de consumo. Considerada dentre as primeiras experiências do cooperativismo brasileiro, a Cooperativa de Consumo dos Operários da Fábrica de Tecidos de CamaragibePernambuco foi fundada nos anos de 1892 a 1895 por iniciativa de Carlos Alberto Menezes, então gerente daquela fábrica. Porém, a exemplo das demais regiões do país, foi no setor agrícola em função das implementações das políticas oficiais, que o cooperativismo mais se expandiu. (PIRES, 2004).

Nesse sentido, segundo Rios (1987), grande parte das cooperativas rurais no Nordeste esteve organizada a partir de uma estrutura de classes, nas quais os postos de comando 
sempre estiveram preenchidos pelos grandes proprietários e pelas lideranças políticas locais e regionais, atendendo a benefícios de pessoas e de grupos específicos. Eis a razão pela qual, o cooperativismo nordestino foi identificado como instrumento de controle do que de mudança social, tendo servido, muitas vezes, como instrumento de transferência de recursos financeiros para os produtores.

Constata-se, hoje, no Nordeste, um esforço de revitalização das práticas cooperativas, através dos diversos fóruns realizados em vários estados na sua grande maioria promovidos pelas entidades representativas do cooperativismo e pelas universidades, sobretudo no que diz respeito à formação do seu quadro social e à capacitação dos seus dirigentes. (PIRES, 2004).

Ainda assim podemos observar que a obra de Pires (2004) Cenários e Tendências do Cooperativismo Brasileiro, parecem revelar uma tendência do cooperativismo atual, ao analisarmos os dados da OCB 2008, no que diz respeito à distribuição das cooperativas no território brasileiro. Podemos constatar que é na região Sudeste que se encontra a maior quantidade de cooperativas, ou seja, $37 \%$ do total. A região nordeste, apresenta a segunda maior concentração de cooperativas do país, ou seja, 25\% das cooperativas existentes. Em seguida a região Sul com $19 \%$ e conseqüentemente as regiões Norte com $10 \%$ do total e a região Centro Oeste com $9 \%$. Como demonstra o gráfico abaixo.

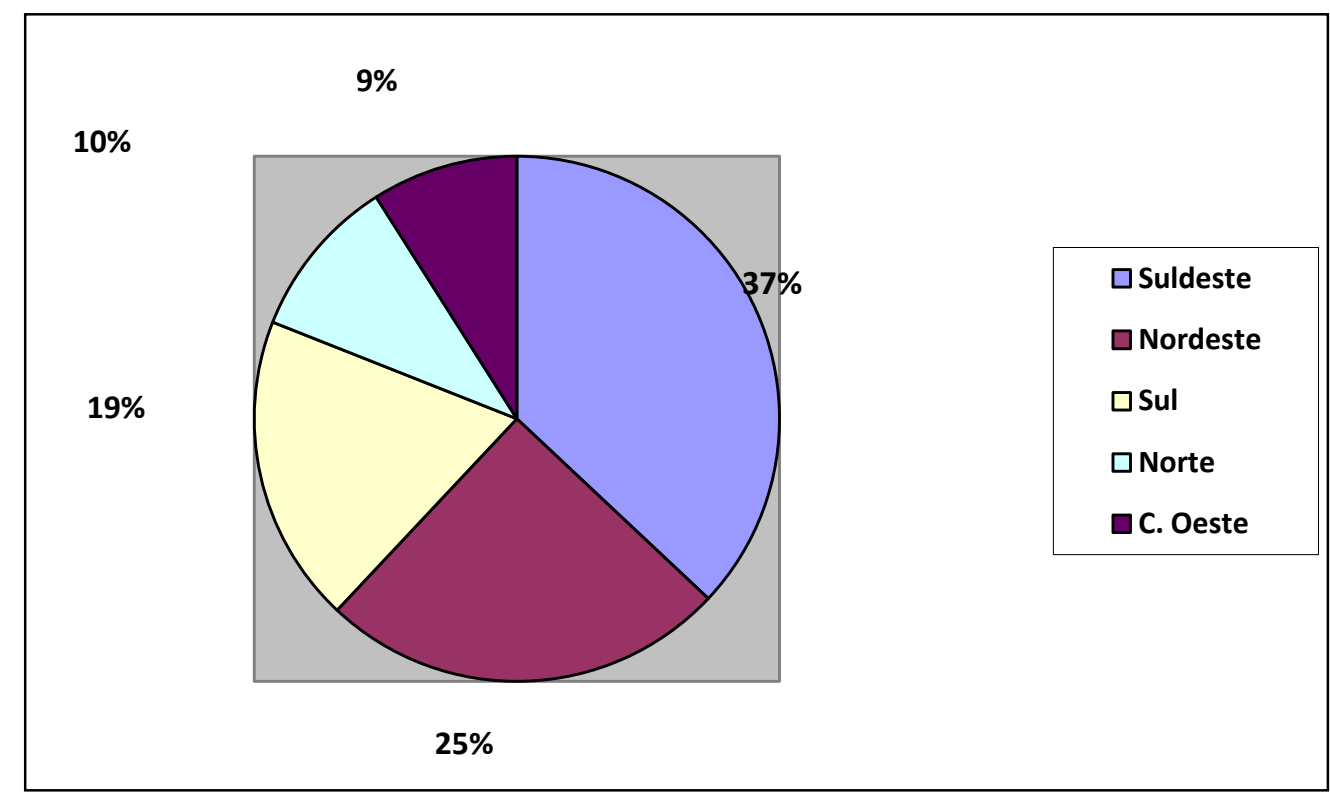

Gráfico 1 - Distribuição das cooperativas nas regiões do Brasil em 2008. Fonte: OCB, 2008.

\section{COOPERATIVA AGOPECUÁRIA}

Dentre esses treze ramos será abordado com maior ênfase o segmento das cooperativas agropecuárias, para que possamos compreender melhor nosso objeto de estudo, em que será priorizando a cooperativa agropecuária COOPAPI, situada no estado do Rio Grande do Norte, na região de Apodi. 
As cooperativas agropecuárias datam de 1907 no estado de Minas Gerais destacando à sociedade de Miraí, em Cataguases. Posteriormente, criaram-se outras cooperativas nos estados de São Paulo, Paraná, Santa Catarina e Rio Grande do sul, com fortes influências dos imigrantes europeus. Este tipo de cooperativa, hoje, está espalhado em todo território nacional, sendo característica de grandes grupos, a maioria voltada para o mercado externo. (BENATO, 1999).

Segundo Pires (2004) no Brasil, as cooperativas agrícolas, ao longo da primeira metade do século $\mathrm{XX}$, não apenas se mostraram como as mais importantes em termos de volumes de negócios como também foram as principais responsáveis pela difusão do ideário cooperativista no país.

No que tange o mercado nacional segundo Veiga (2001) destaca que ultimamente, as cooperativas de produtores rurais, estão abrindo seções de consumos em lojas, feiras, pequenos supermercados, para atender as necessidades dos cooperados e mesmo da sociedade em geral.

Cooperativa agropecuária é segundo a Organização das Cooperativas Brasileiras (2008), Uma cooperativa de produtores rurais ou agropastoris e de pesca, cujos meios de produção pertencem ao cooperado. Caracterizam-se pelos serviços prestados aos associados, como recebimento ou comercialização da produção conjunta, armazenamento e industrialização, além da assistência técnica, educacional e social.

No âmbito do mercado internacional as exportações diretas das cooperativas brasileiras, no acumulado de janeiro a dezembro de 2008, registraram um crescimento de 21,49\% em relação a 2007 , somando US\$ 4,01 bilhões. No ano anterior, esse valor foi de US\$ 3,3 bilhões. Os resultados fazem parte de um estudo da Gerência de Mercados (Gemerc), da Organização das Cooperativas Brasileiras (OCB), elaborado com base em dados da Secretaria de Comércio Exterior do Ministério do Desenvolvimento, Indústria e Comércio Exterior (MIDC).

As cooperativas agropecuárias vem desenvolvendo ao longo dos anos um bom desempenho comercial no mercado nacional e internacional. Se consolidando no mercado internacional com taxas de crescimento significativas. Esse resultado pode ser demonstrado logo abaixo diante da balança comercial analisada no período de 2004 a 2008. Onde alguns fatores servem de destaque para esse resultado, como investimentos em estratégias comerciais, abertura de mercado, melhoria na qualidade dos produtos e assistência técnica entre outros. 


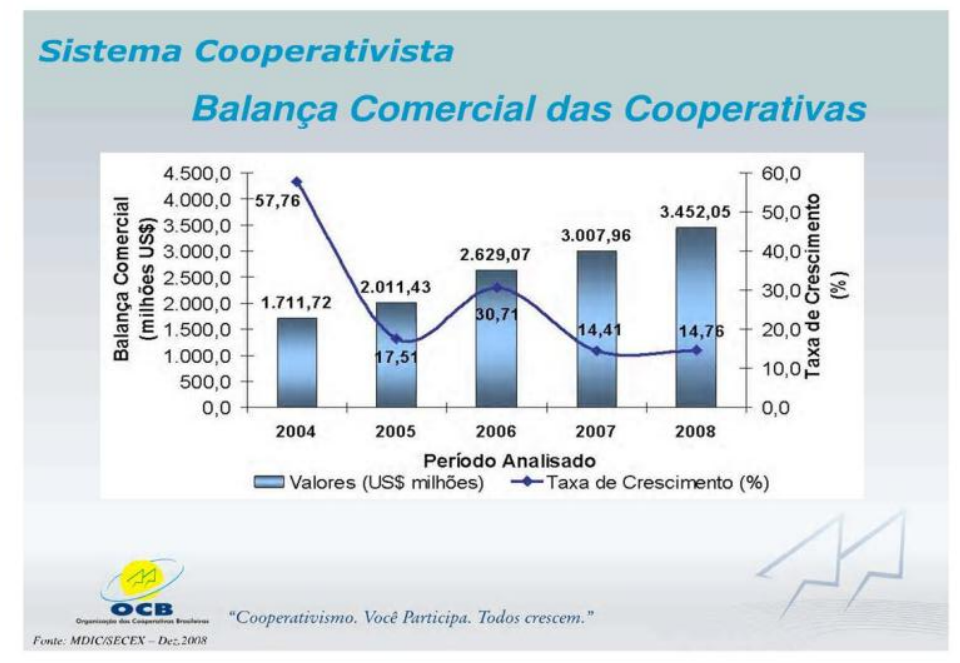

Ilustração 2 - Participação das Cooperativas na Balança Comercial de 2004 a 2008.

Fonte: Organização das Cooperativas Brasileiras (OCB, 2008).

Segundo a Organização das Cooperativas Brasileiras (2008) são contabilizadas no Brasil 1.611 cooperativas agropecuárias, tendo 968.767 cooperados e gerando 134.579 empregos, onde os maiores importadores de produtos agrícolas do Brasil são: Alemanha, Países Baixos, China, EUA e Japão.

A Alemanha e os Países Baixos se destacaram nas importações dos produtos comercializados pelas cooperativas. Em 2008, a Alemanha representou 11,27\% das exportações, com um total de US\$ 452 milhões, puxadas pelas vendas dos produtos do complexo soja, com destaque para o farelo e para o grão, e pela comercialização de café (ORGANIZAÇÃO DAS COOPERATIVAS DO BRASIL, 2008).

Os Países Baixos mostraram uma participação de 10,36\% e importações de US\$ 415,43 milhões, explicadas pelas aquisições de produtos do complexo de soja, com destaque para a soja em grão e para o farelo de soja. O álcool figura na segunda posição de produtos, com vendas totais de US\$111,14 milhões em 2008. (OCB, 2008).

Em seguida, está a China com uma parcela de 10,12\% e US\$ 405,94 milhões em importações, no acumulado de janeiro a dezembro de 2008. O complexo de soja mostrou liderança absoluta nas vendas externas para a China com um total de US\$ 400,08 milhões (OCB, 2008).

Os Estados Unidos foram responsáveis por um total de US\$ 363,85 milhões nas importações o que representa $9,07 \%$ do total exportado pelas cooperativas em 2008 . No mesmo período do ano anterior, a participação foi de 5,58\%. Os produtos do setor sucroalcooleiro apresentaram liderança na pauta, com vendas totais de álcool de US\$ 309,36 milhões, o que representou 85,02\% das exportações das cooperativas em 2008. 
Destaque para as vendas de álcool com uma elevação de $131,68 \%$ ao logo dos dois últimos anos.

O Japão, a Rússia e a Arábia Saudita aparecem na seqüência, com participações de 6,53, 5,11 e $4,02 \%$, respectivamente (OCB, 2008).

Os principais produtos exportados pelas cooperativas brasileiras são a soja, complexo sucroalcoleiros e carnes. As exportações de soja em grão atingiram US\$ 680,03 milhões, mostrando liderança nesse grupo de produtos, frente ao farelo (US\$ 405,51 milhões) e ao óleo (US\$ 184,14 milhões). Na sequiência do ranking figuram as exportações do setor sucroalcooleiro, com vendas de US\$1,08 bilhão, sendo o álcool de US\$ 588,79 milhões e o açúcar, US\$ 490,84 milhões. As vendas externas desse setor foram destaque nas exportações em 2007. Contudo, as vendas de açúcar mostraram queda de $35,53 \%$ e, dessa forma, o setor apresentou uma retração de $0,27 \%$ nos valores comercializados em relação ao ano anterior (OCB, 2008).

As vendas das carnes somaram US\$ 814,61 milhões nos meses de janeiro a dezembro de 2008, tendo-se liderança das aves (US\$ 468,54 milhões), seguidas pelas carnes de suínos (US\$ 166,03), outras carnes e carnes secas (US\$ 137,07 milhões) e pela carne bovina (US\$ 42,98 milhões). As aves representaram 58\% das vendas externas desse setor em 2008 e 57\% no mesmo período de 2007, caracterizadas como principal produto dessa origem. As carnes, suína e bovina apresentaram em 2008 uma participação de $25 \%$ e $5 \%$, respectivamente. (OCB, 2008).

No que tange os estados brasileiros com maior participação nas exportações podemos destacar Paraná, São Paulo e Minas Gerais como os principais estados participantes, onde as cooperativas do Paraná foram às maiores exportadoras no acumulado de janeiro a dezembro de 2008 , com uma parcela de $35,97 \%$ do total e um valor absoluto de US\$ 1,44 bilhão. (OCB, 2008).

Considerando o ano de 2007, o estado de São Paulo havia mostrado maior participação, com um total exportado de US\$ 1,07 bilhão, ou seja, 32,51\% do total. Contudo, no período seguinte, o estado apresentou redução de US\$121,63 milhões nas vendas e, dessa forma, representa $23,72 \%$ do total exportado pelas cooperativas brasileiras. (OCB, 2008).

As exportações das cooperativas de Minas Gerais foram de US\$ 410,56 milhões em 2008, participação de 10,24\%. O estado mostrou uma taxa de crescimento de $15,01 \%$, pois, no período anterior, as vendas somaram US\$ 356,98 milhões. Os três estados citados somados representaram 75,21\%, 69,93\% dos valores, entre janeiro a dezembro dos anos de 2007 e 2008, respectivamente, o que demonstra o aumento da participação de cooperativas de outros estados, como o Rio Grande do Sul, Santa Catarina, Mato Grosso e Goiás. (OCB, 2008).

\section{EXPORTAÇÃO DE MEL}

No âmbito das exportações de 2009 podemos considerar que estas continuam em expansão. Em março, o país vendeu três mil toneladas, correspondentes ao valor de US\$ 7, 216 milhões, um incremento de 11,9\% em relação a fevereiro (US\$ 6.446 milhões). 
O crescimento é ainda maior em comparação com março de 2008, quando foram exportadas cerca de 991.000 toneladas em peso e US\$ 2,088 milhões em valor. (Alice web).

Os números provam que a crise mundial não repercutiu na apicultura. Só no primeiro trimestre de 2009, foram exportadas 7,4 mil toneladas de mel, gerando uma receita de US\$ 17,49 milhões. No mesmo período do ano passado, o País exportou apenas 3, 264 mil toneladas, alcançando uma receita de US\$ 6, 239 milhões. (SEBRAE, 2009).

Os principais destinos das exportações brasileiras foram os Estados Unidos que responde por mais da metade das importações, ou seja, $(58,2 \%)$ da receita total, ao preço de US\$2,82/kg. A Alemanha foi o segundo mercado, com receita de US\$1,4 milhão, significando $21,2 \%$ do valor total exportado, ao preço de US\$2,98/kg. O Reino Unido absorveu $13,6 \%$ das exportações, com total de US\$ 941 mil, pagando $2,83 / \mathrm{kg}$. O estado Rio Grande do Norte exportou cerca de US\$ 4.490 milhões e 1.950 quilos, dos meses de janeiro a dezembro de 2009, sendo o principal consumidor os EUA com receita de US\$ 4.344 milhões e 1.892 quilos. (Alice web).

Com relação ao mercado brasileiro, o estado que mais exportou foi São Paulo, com US\$ 1,6 milhão. Rio Grande do Sul veio em seguida, com US\$ 1,19 milhão. O terceiro lugar ficou com Ceará, com receita de US\$ 1,17 milhão, seguido pelo Piauí, com US\$ 1 milhão. (Alice web).

Em 2009 a Central de Cooperativas Apícolas do Semi-Árido Brasileiro (Casa Apis) que reúne nove cooperativas, produziu 400 toneladas de mel, das quais 200 toneladas foram vendidas para o governo brasileiro utilizar na merenda escolar, e as outras 380 toneladas seguiram para os EUA e para a Europa. "Para exportar mel, os produtores precisam ter qualidade, ficando atentos a questão dos controles sanitários e alfandegários, e volume", (SEBRAE, 2009, p.?) ${ }^{4}$.

Alguns fatores são intervenientes para o aumento na demanda das exportações brasileiras de mel um deles é que, provavelmente os estoques internacionais de mel ainda continuam abaixo dos níveis normais, caracterizando-se uma situação de "vazio de oferta", onde as quantidades produzidas/ofertadas são inferiores aos volumes demandados. (SEBRAE, 2009).

Outro fator determinante é a queda na produção nacional de mel (safra 2009), em função de estiagem/seca nas regiões Norte e Nordeste e excesso de chuvas na região Sul e Sudeste, associado a um quadro similar em várias partes do mundo, com problemas climáticos em muitos países produtores (secas, enchentes, incêndios). (SEBRAE, 2009).

No que tange as exportações de mel em 2010, estas foram marcadas pela estabilidade de preço, onde as exportações somaram US\$ 4.124.983,00 e 1.432.599,00 quilos. O preço médio do mel praticamente ficou estável, em US\$2,88/kg, embora tenha sido $11 \%$ maior que os US\$2,59/kg de mel pagos em maio de 2009. (Alice web).

\footnotetext{
${ }^{4}$ Documento retirado da internet.
} 
Quanto à classificação das exportações por estados a liderança continuou sendo de São Paulo, com US\$ 1.292.652,00 exportados, respondendo, sozinho, por $31 \%$ das exportações brasileiras de mel. O Piauí assumiu o segundo lugar na exportação brasileira de mel, com US\$ 978.134,00, que representou $24 \%$ do total exportado. O terceiro colocado foi o Ceará (US\$ 712.327,00). (SEBRAE, 2010).

O quarto exportador foi Santa Catarina, com uma receita de US\$ 621.247,00, seguido, em quinto lugar pelo Rio grande do Norte (US\$232.288,00). O Rio Grande do Sul foi o sexto exportador (US\$ 165.077/kg). O penúltimo exportador foi o Paraná (US\$ 122.548,00). Minas Gerais foi o oitavo e último exportador (US\$ 64,55), referentes a apenas onze quilos e mel, provavelmente, fracionado e como amostra. (SEBRAE, 2010).

No que se refere ao destino das exportações podemos dizer que até maio de 2010, 17 países importaram mel do Brasil. O principal destino das exportações brasileiras de mel foram os Estados Unidos, que responderam por mais da metade $(52,6 \%)$ do total comercializado, com uma receita de exportação US\$ 12,41 milhões, a um preço de US\$ 2,79/kg de mel. (SEBRAE, 2010).

O principal mercado na Europa foi à Alemanha, que importou US\$ 5,95 milhões de mel do Brasil a um preço de US\$2,95/kg, equivalendo a mais de um quarto $(25,2 \%)$ do total das exportações. O Terceiro destino do mel brasileiro foi o Reino Unido, com US\$3,22 milhões, ao preço e US\$2,87/kg. (SEBRAE, 2010).

O crescimento contínuo das exportações verificado desde o fim de 2009 deve-se provavelmente aos baixos estoques internacionais. Pelo terceiro ano consecutivo, a produção Argentina será negativamente afetada pela seca que já atinge $90 \%$ desse país. Em 2009, os EUA colheram a sua pior safra de mel da história, inferior a 55 mil toneladas. (SEBRAE, 2010, p.?) ${ }^{5}$

O crescimento das exportações tem se mostrado positivo com o passar dos anos, ganhando não só o mercado nacional como o internacional. No entanto é necessário, um maior desenvolvimento nesse setor, como por exemplo, a inserção de políticas públicas no meio rural, onde o agricultor não precise passar por determinados problemas, sejam eles técnicos ou climáticos, principalmente voltados para a escassez de água, elemento natural que afeta toda a cadeia apícola.

\section{AGRICULTURA FAMILIAR}

Ao se pensar em cooperativa agropecuária não se deve esquecer a importância da agricultura familiar que apesar de não aparecer nos dados da exportação, chegam a representar $60 \%$ do abastecimento do mercado interno com produtos básicos da dieta brasileira. Embora no Brasil tem-se agricultura familiar como uma atividade de pequeno porte, que emprega majoritariamente famílias, segundo o ministério do desenvolvimento agrário, é esta atividade que vem evitando fenômenos como o do êxodo rural e que abastece com produtos da dieta básica a maioria da população do país.

\footnotetext{
${ }^{5}$ Documento retirado da internet.
} 
A chamada agricultura familiar constituída por pequenos e médios produtores representa a imensa maioria de produtores rurais no Brasil. São cerca de 4,5 milhões de estabelecimentos, dos quais $50 \%$ no Nordeste. O segmento detém $20 \%$ das terras e responde por $30 \%$ da produção global. Em alguns produtos básicos da dieta do brasileiro como o feijão, arroz, milho, hortaliças, mandioca e pequenos animais chegam a ser responsável por $60 \%$ da produção. Em geral, são agricultores com baixo nível de escolaridade e diversificam os produtos cultivados para diluir custos, aumentar a renda e aproveitar as oportunidades de oferta ambiental e disponibilidade de mão-deobra. (EMBRAPA, 2008, P.?). ${ }^{6}$

O modelo familiar teria como característica a relação íntima entre trabalho e gestão, a direção do processo produtivo conduzido pelos proprietários, a ênfase na diversificação produtiva e na durabilidade dos recursos e na qualidade de vida, a utilização do trabalho assalariado em caráter complementar e a tomada de decisões imediatas, ligadas ao alto grau de imprevisibilidade do processo produtivo (FAO/INCRA, 1994).

\begin{abstract}
Quando se estuda a agricultura é possível identificar a existência de diversos tipos de produtores, que se diferenciam por suas condições socioeconômicas, por suas tomadas de decisão e pela maneira que empregam suas práticas agrícolas. Tal diversidade é capaz de ser identificada numa mesma categoria de produtores, podendo-se diferencia - los pela forma de acesso a terra, ao crédito rural, às políticas públicas e recursos naturais, da mesma forma que não apresentam o mesmo nível de capitalização, modo de organização e relacionamento com os agentes das categorias sociais que mantêm em seu entorno. Mesmo que se compreendam os sistemas de cultivo, criação e de transformação, isoladamente, a atividade agrícola é bastante complexa, por combinar os diferentes recursos à disposição do agricultor com um diversificado conjunto de práticas agrícolas. Até mesmo a unidade de produção agrícola especializada e que pratica a monocultura pode ser dotada de complexidade e diversidade. Assim, a evolução de cada tipo de produtor e de sistemas de produção é determinada por um complexo conjunto de fatores ecológicos, técnicos, sociais e econômicos relacionando-se ao longo da história. (INCRA/FAO, 1999, p.?). ${ }^{7}$
\end{abstract}

\title{
ECONOMIA SOLIDÁRIA
}

Nas ultimas décadas a conjuntura econômica, política e social brasileira foi marcada por uma estrutura de desemprego crescente e exclusão social, onde a maioria dos trabalhadores e famílias tiveram que se adaptar diante desse cenário. Diante dessa perspectiva surgem outras propostas de economia igualitária e democrática como: o cooperativismo, economia solidária, economia social ou economia popular, melhorando a qualidade de vida dessas famílias, não só econômica como também social e humano em geral.

Segundo pesquisadores e os adeptos da causa da economia solidária, ela não se resume ao cooperativismo, mas esse é a sua forma principal, pois tem fundamentos éticos de organização e uma tradição histórica. Nessa perspectiva, a economia solidária vai além, portanto, do cooperativismo, abrangendo outras formas de organização econômica, mas com a mesma orientação igualitária e democrática. Ou seja, são experiências baseadas em valores coletivistas e não individualista (SINGER, 2003).

\footnotetext{
${ }^{6}$ Documento retirado da internet.

${ }^{7}$ Ibidem.
} 
Para Singer (2003) a economia solidaria defende princípios de autogestão, participação igualitária e transparência que se identificam com a democracia participativa. As chamadas correntes participacionistas da teoria democrática nasceram em contraposição às correntes concorrenciais que se tornaram hegemônicas na teoria política contemporânea.

Entretanto, Singer (2003) enfatiza que muitos autores interpretam a economia solidária como forma de resistência dos setores populares à crise no mundo de trabalho e o quadro de exclusão social. Entre eles, vários enxergam, além do caráter emergencial e imediato, também um potencial de transformação social e entendem a economia solidária não só como necessidade material, mas também como uma opção ideológica.

Segundo Singer (2000), a economia solidária surge como modo de produção e distribuição alternativas ao capitalismo, criado e recriado periodicamente pelos que se encontram (ou temem ficar) marginalizadas no mercado de trabalho. A economia solidária casa o princípio da unidade entre posse e uso dos meios de produção e distribuição (da produção simples de mercadorias) com o princípio da socialização destes meios.

A Economia Solidária ganha destaque no Brasil principalmente nos anos 80. Hoje considerada um movimento, em nível de Brasil, está estrutura através da Secretária Nacional de Economia Solidária (SENAES), criada em 2003, pelo governo federal, ligada ao Ministério de Trabalho e Emprego. Nesse sentido compreende-se por economia solidária segundo (BRASIL, 2009) o conjunto de atividades econômicas de produção, distribuição, consumo, poupança e crédito, organizados sob a forma de autogestão. Solidária é um jeito diferente de produzir, vender, comprar e trocar o que é preciso para viver. Sem explorar os outros, sem querer levar vantagem, sem destruir o ambiente. Cooperando, fortalecendo o grupo, cada um pensando no bem de todos e no próprio bem.

\begin{abstract}
A economia solidária vem se apresentando, nos últimos anos, como inovadora alternativa de geração de trabalho e renda e uma resposta a favor da inclusão social. Compreende uma diversidade de práticas econômicas e sociais organizadas sob a forma de cooperativas, associações, clubes de troca, empresas autogestionárias, redes de cooperação, entre outras, que realizam atividades de produção de bens, prestação de serviços, finanças solidárias, trocas, comércio justo e consumo solidário (MTE, 2009,p. ?). ${ }^{8}$
\end{abstract}

Entretanto a globalização trouxe inúmeras vantagens para os diversos setores econômicos no Brasil. Podemos dizer que, com essa aproximação os setores que mais tiveram destaque foram: tecnológicos e científico, ou seja, a indústria informática, de telecomunicações, farmacêutica, automobilística entre outras. Juntamente com essa revolução tecnológica e a entrada de grandes multinacionais no país, empresas que são geralmente estrangeiras, verificou-se uma acirrada concorrência no mercado entre as empresas já existentes.

Com esse desenvolvimento, podemos destacar vários pontos negativos advindos dessa nova realidade brasileira, ou seja, muitos desses empreendimentos não conseguiram

\footnotetext{
${ }^{8}$ Documento retirado da internet
} 
sustentar-se com a nova concorrência desleal, partindo das grandes indústrias, ocorrendo o desemprego, falência de algumas empresas, redução salarial dentre outros.

Diante desse cenário surgi à necessidade de mudança no comportamento dos trabalhadores, ou seja, a transformação de empresa tradicional, como empregado, para um novo tipo de empreendimento o autogestionário, que segundo Tauile et al (2005), podemos dizer que o fenômeno das empresas autogestionárias é constituído no Brasil por experiências resultantes de processos falimentares, que buscam, a partir da democratização da posse dos meios de produção, avançar também para a democratização da forma de gestão das empresas através da aplicação dos princípios da autogestão.

De forma geral, as empresas autogestionárias no Brasil ganharam projeção como resposta dos trabalhadores ao período de crise econômica na década de noventa. Essa crise foi disparada e agravada pelas medidas de cunho neoliberal implementadas desde o governo Collor, repercutindo num processo profundo de ajuste estrutural do capital aos novos parâmetros de acumulação capitalista globalmente (TAUILE et al, 2005).

Duas dimensões emergem do processo de consolidação de cooperativas e outra formas de economia solidária: uma dimensão econômica, enquanto atividades econômicas que garantem meios de vida aos seus integrantes; e uma dimensão política, enquanto organização coletiva onde prevaleçam práticas democráticas, cooperativas e autogestionárias entre os integrantes. Embora muitas vezes apenas umas delas tenda a ser enfatizada, ambas são fundamentais para que a economia solidária se concretize. (SINGER, 2003).

Portanto a economia solidária é vista, como um instrumento de combate à exclusão social, e apresenta alternativa para a geração de trabalho e renda e para a satisfação direta das necessidades de todos, diante disso, verifica-se um ponto primordial para o desenvolvimento não só da cooperativa, empreendimento autogestionário ou qualquer tipo de empreendimento, o modo como ela é gerido ou administrado, ou seja, a gestão, sendo vista como fator decisório para a sustentação e participação da empresa no mercado consumidor que, cada vez mais está exigente e seletivo, seja ele nacional ou internacional.

\section{GESTÃO COOPERATIVISTA}

O fator contingencial mais importante do desenho organizacional são as pessoas, o elemento fundamental que impulsiona a organização para a ação. Hoje o maior desafio das cooperativas é tentar equilibrar os interesses sociais, econômicos e políticos de seus participantes, dai a importância de uma boa gestão participativa. Onde, a atual rapidez na tomada de decisões acaba tornando-se fator primordial para o sucesso da organização.

Um dos fatores primordial desse elemento é a chamada gestão, que segundo Oliveira (2001, p. 67) "gestão pode ser conceituada como o processo interativo de desenvolver e operacionalizar as atividades de planejamento, organização, direção e avaliação dos resultados da cooperativa". 
Segundo Abrantes (2004) a gestão deve se a mais democrática possível, devendo haver um sistema de decisões que conte com a participação de todos os associados. Para isso é fundamental que haja uma perfeita e constante comunicação entre todos. Baseado no tamanho e no tipo da cooperativa, pelo menos no inicio das atividades, pode-se propor a estrutura organizacional mostrada no organograma a seguir.

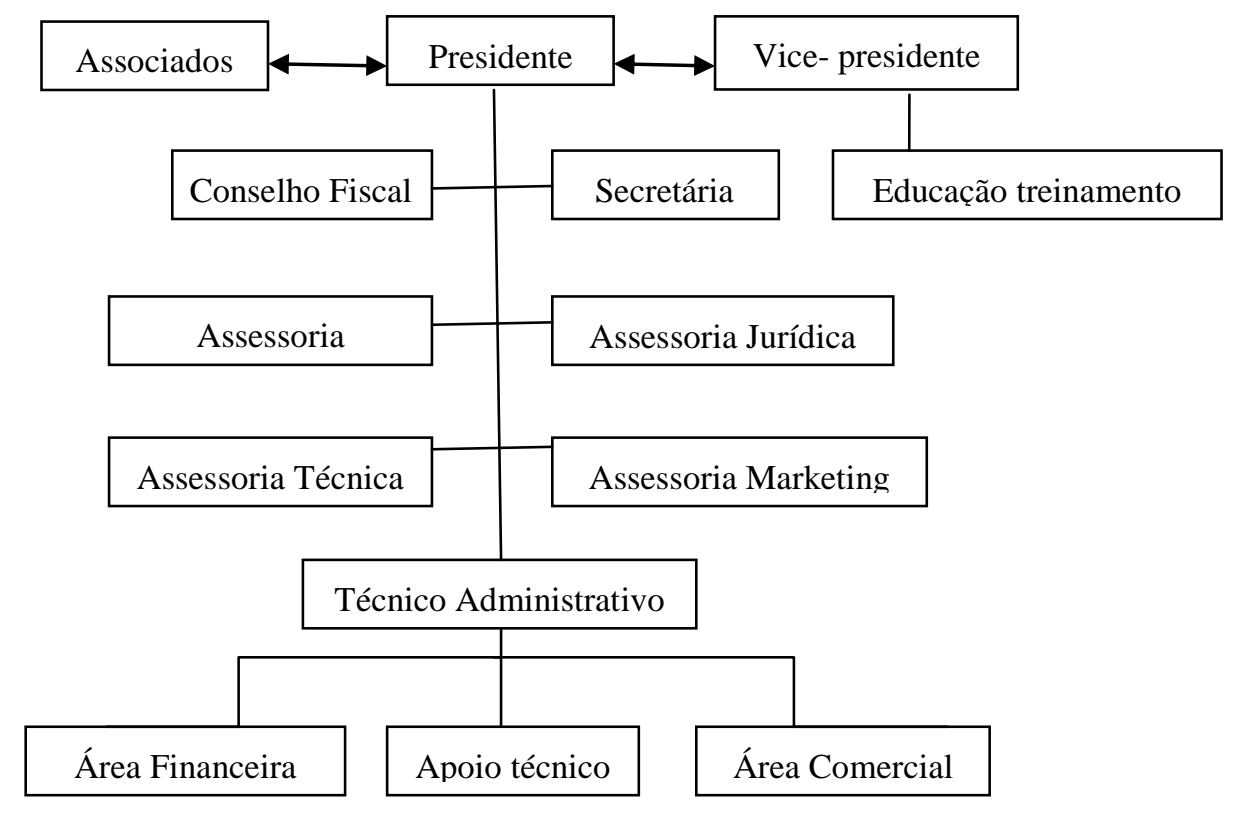

Organograma 1 - Estrutura Organizacional da Cooperativa Fonte: Abrantes (2004).

Para Abrantes (2004), a maior responsabilidade cabe aos associados, que devem manter o espírito de pioneirismo, baseado na filosofia cooperativista. Todos são responsáveis pelo sucesso da cooperativa. Todos são os donos e todos têm que participar e não apenas delegar poderes aos membros da diretoria. Deve ser lembrado que pode- se delegar autoridade, nunca a responsabilidade, que neste caso é de todos. É importante ter muito bem definido que apesar de toda esta participação, os associados não devem interferir de forma direta nos aspectos empresariais, só o fazendo através das assembléias gerais.

Um aspecto importante e determinante na gestão das cooperativas é a autogestão. De acordo com Storch (1987) a autogestão envolve não apenas a participação através de representantes, mas também a participação direta. $\mathrm{O}$ conceito está ligado à participação e ao controle, e não à propriedade.

Segundo Cançado (2007) a autogestão é o modo de organização do trabalho, onde não há separação entre concepção e execução do trabalho e os meios de produção são coletivos, sendo caracterizado como o processo de educação em constante construção na organização.

A autogestão deveria ser totalmente diferente da gestão capitalista, pois por todos terem o mesmo nível participativo (pelo menos deveriam e é de direito terem), há uma redução de conflitos em diversos setores, e há uma transparência de todo o processo. Para as empresas autogeridas as informações relevantes são disponibilizadas, bem como 
a contabilidade e os sistemas de controle, para que todos possam participar das decisões (SINGER, 2000).

Por outro lado, a heterogestão, em contraposição a autogestão, é consolidada na organização burocrática do trabalho, baseada em cadeias de comando, criando hierarquia. Estas cadeias de comando (ou linhas de comando) mostram claramente a questão da submissão, quem esta abaixo é comandado por quem esta acima, seguindo a lógica de uma pirâmide, aonde a muitos na base e o número vai diminuindo à medida que se chega aos cargos mais altos (CANÇADO, 2007).

Para Tauile at at (2005) das formas de gestão socialmente indesejável, temos a heterogestão. Trata-se da forma capitalista usual de organização das unidades produtivas, em que se opera a separação rígida entre as esferas de concepção e execução das atividades, entre planejamento e produção. $\mathrm{O}$ autor demonstra também em seus estudos, que a co-gestão é mais avançada do que a heterogestão camuflada, pois ai a dualidade de poderes é instituída, com a permanência dos proprietários ou de um quadro gerencia profissional nas funções de direção da empresa.

Contudo, podemos concluir que a autogestão ainda é algo do tipo ideal desejado e que se espera atingir seus objetivos em um curto espaço de tempo, chega-se a essa conclusão embasada na afirmação de Singer (2000), que para uma organização do trabalho em regime autogerido nota-se que os modelos administrativos são falhos, pois foram criados originalmente para gerir empresas capitalistas. $\mathrm{O}$ trabalho em empresas autogestionárias, em princípio, mostra-se mais útil e menos penoso do ponto de vista do trabalhador. As novas características associadas a essas empresas tornam-nas mais participativas e menos centralizadoras. E ao deterem os meios de produção- de forma coletiva- precisam organizar a gestão de modo a abranger todas essas novas características. A par disso ainda há descrença de que "meros" trabalhadores possam administra empresas, sendo essa administração entendida como ciência a ser operada por especialistas.

\section{DIFICULDADES ENFRENTADAS NA GESTÃO COOPERATIVISTA}

Deve-se ressalta que, para a gestão cooperativista a forma de administração deve ser conjunta com atuação mútua entre os cooperados. O desenho organizacional deve dar apoio e suporte que as pessoas necessitam para alcançar tanto os objetivos organizacionais como para obter satisfação em seu trabalho.

Diante disso têm-se identificado algumas fragilidades dentro das organizações cooperativistas, ou seja, um dos problemas de bastante relevância é que, devido à quantidade de participantes nas cooperativas a comunicação tende a ser de difícil acesso.

Juntamente como a participação entre os cooperados, deve-se ter um plano organizacional compreendidos por todos, ou seja, para ocorrer uma boa gestão dentro da cooperativa é necessário que todos os cooperados participem desde o processo de planejamento até a implementação dos objetivos. 
Na visão de Oliveira (2006), os principais problemas identificados na gestão das cooperativas são a falta ou o esquecimento da educação cooperativista; a falta de cooperação entre as cooperativas; a aplicação de modelos de gestão centralizados, inadequados e desatualizados; o fato de não saber atuar com a concorrência e a confusão entre propriedade da cooperativa e propriedade de gestão.

Diante disso e do atual cenário de competitividade e globalização, Oliveira (2006, p. 32) salienta "que as cooperativas terão que decidir qual é a delas perante as empresas concorrentes - cooperativas ou não", tendo em vista que estão ocorrendo várias alterações de maior ou menor amplitude nas mesmas.

Há de se ressaltar outra dificuldade encontrada na gestão das cooperativas é que a cultura da heterogestão ainda sobrepõe à cultura autogestionária não só no Brasil mais em diversos países, que segundo Singer (2003), isso acontece por que alguns trabalhadores têm saudades dos tempos de patrão, quando não precisavam preocupar-se com os resultados do trabalho.

Para que esses "novos patrões" possam seguir uma linha de orientação, a lei n ${ }^{\circ} 5.764$, de 16 de dezembro de 1971, que define a Política Nacional de Cooperativismo, institui o regime jurídico das sociedades cooperativas e no que tange as normas administrativas e fiscais da cooperativa, a seção IV com base nos artigos 47 e 48 dos órgãos administrativos dispõe o seguinte:

Art. 47. A sociedade será administrada por uma Diretoria ou Conselho de Administração, composto exclusivamente de associados eleitos pela Assembléia Geral, com mandato nunca superior a 4 (quatro) anos, sendo obrigatória a renovação de, no mínimo, 1/3 (um terço) do Conselho de Administração.

Art. 48. Os órgãos de administração podem contratar gerentes técnicos ou comerciais, que não pertençam ao quadro de associados, fixando-lhes as atribuições e salários.

No que tange ao conselho fiscal a seção $\mathrm{V}$ do conselho fiscal artigo 56 dispõe que:

Art. 56. A administração da sociedade será fiscalizada, assídua e minuciosamente, por um Conselho Fiscal, constituído de 3 (três) membros efetivos e 3 (três) suplentes, todos associados eleitos anualmente pela Assembléia Geral, sendo permitida apenas a reeleição de 1/3 (um terço) dos seus componentes.

Ainda há muito trabalho a ser feito dentro dessas associações, um deles é o de conscientização dos próprios cooperados, de que eles são proprietários do seu negócio, ou seja, terão que se adaptarem a realidade de administrar sua cooperativa de cooperar e estudar, adotando medidas estratégicas para que o seu desenvolvimento seja sempre continuo.

\section{ESTRATÉGIAS COOPERATIVISTAS}

A competitividade de uma empresa consiste na sua capacidade de formular e delinear estratégias que lhe permitam manter, em longo prazo, sua posição relativa no mercado. As cooperativas brasileiras que não foram eliminadas pela acirrada concorrência, 
buscam constantemente estratégias que se traduzem em redução de gastos, aumento de eficiência e de produtividade. Sejam através da fusão ou incorporação das cooperativas. Veiga (2001) afirma que gestão estratégica é a parte da gestão global das organizações que acompanha as ações das empresas para monitorar, conceber e implantar estratégias para que, assim, se mantenham competitivas no mercado.

Considerando os aspectos estratégicos, organizacionais, diretivos e de avaliação, as principais tendências do cooperativismo são: o incremento do nível de cooperação entre pessoas, grupos, atividades e regiões; a ampliação e o fortalecimento do nível de concorrência entre as empresas e as cooperativas enfatizadas pela criação de vantagens competitivas reais, sustentadas e duradouras; o enxugamento das estruturas organizacionais; a questão do tamanho ideal através da evidência de que ser o maior não é ser o melhor; o aumento das fusões entre as cooperativas; o redirecionamento da estrutura de poder; a consolidação da qualidade total que passa a ser considerada uma premissa e não apenas um objetivo a ser alcançado; a aceleração da evolução tecnológica; a redução do ciclo de vida dos produtos e negócios; bem como dos desperdícios; a globalização das atividades das cooperativas; a profissionalização de cooperados e de cooperativas além da sua atuação no novo contexto ecológico (OLIVEIRA, 2006).

Podemos avaliar dentro da estrutura organizacional cooperativa, alguns aspectos estratégicos para Abrantes (2004) são: a secretaria ou o secretario que tem a função estratégica, pois é quem fará os contatos com os associados, consumidores e fornecedores. Deve ser um profissional experiente, educado com fácil relacionamento e muito bem treinado na arte de atendimento aos clientes. É muito importante que os contatos, em especial aos comerciais, sejam feitos por intermediário a essa função para se evitar, por exemplo, que os associados negociem de forma isolada com clientes ou fornecedores.

Outro aspecto estratégico importante segundo Abrantes (2004) é o técnico administrativo que também tem uma função estratégica, sendo responsável pela administração e os dados financeiros, contábeis e comerciais, além de viabilizar o apoio técnico aos associados e clientes. E a assessoria técnica ${ }^{9}$, nesse caso deve-se lançar mão de um profissional da área agrícola. Este profissional, que deve ser agrônomo, terá muito a ensinar e orientar os produtores, tanto a produção em si quanto nos traços para evitar as referidas pragas e doença.

\section{ANÁLISE DE DADOS DA COOPERATIVA COOPAPI}

Ao analisarmos os dados obtidos é necessário conhecermos primeiramente o município no qual foi realizada a pesquisa. Apodi está localizado na Mesorregião do Oeste Potiguar, mas precisamente na Microrregião da chapada do Apodi, com uma área de territorial de 1.555,5 quilômetros quadrados, equivalente a 2,92\% do estado do Rio Grande do Norte, com uma população de 31.154 habitantes, apresentando uma densidade demográfica de 20,08 pessoas por quilômetros quadrados.

\footnotetext{
${ }^{9}$ Caso seja uma cooperativa agropecuária, como é o caso da cooperativa em estudo.
} 
O município é cortado pela BR 405 e banhado pelo Rio Apodi/Mossoró, Situa-se na região de transição do calcário da formação Jandaira e é cortada no sentido Sul/Norte pelo rio Apodi, tendo como destaque a tradicional Lagoa do Apodi, com quase 13 quilômetros de extensão, onde se localiza o Balneário e a Barragem de Santa Cruz, com capacidade para armazenar cerca de 600 milhões de metros cúbicos d'água, Em Apodi está localizado o Sítio Arqueológico do Lajedo de Soledade, localizado na Vila de Soledade, a maior constituição rochosa da bacia potiguar e onde processa o maior fluxo turístico do município, para visitação ao Museu e as grutas históricas onde estão as pinturas rupestres com milhares de anos.

A economia do município de Apodi esta voltada para a produção de petróleo, água mineral, refrigerante e conta com uma cadeia produtiva muito forte, com destaque para a cajucultura, ovinocultura, bovinocultura, caprinocultura, piscicultura, apicultura, cultura do arroz irrigado no vale e conta com o segundo maior reservatório de água do Estado, Parque Arqueológico do Lajedo de Soledade, solo de excelente qualidade.

\section{APICULTURA}

Diante de todo esse estudo conceitual iremos abordar agora o estudo de caso feito na cooperativa COOPAPI, uma cooperativa de apicultores no município de Apodi, no estado do Rio Grande do Norte, para isso, vamos identificar no primeiro momento a importância da apicultura e as vantagens de se produzir o mel.

E necessário que verifiquemos a importância do mel como alimento a ser inserido na dieta e no cotidiano dos seres humanos, ou seja:

"O mel é um alimento importante para o homem como fonte de energia, contribuindo para o equilíbrio do processo biológico do corpo humano, principalmente por conter proporções adequadas de vitaminas, substancia aromáticas, fermentos e aminoácidos". (CANÇADO, 2007 apud Trevisan e Outoros,1981 p.24).

Segundo Pereira et al (2002) a apicultura é uma das atividades capazes de causar impactos positivos, tanto sociais, ambientais quanto econômicos, além de contribuir para a manutenção e preservação dos ecossistemas existentes. A cadeia produtiva da apicultura propicia a geração de inúmeros postos de trabalho, empregos e fluxo de renda, principalmente no ambiente familiar, sendo, dessa forma, determinante na melhoria da qualidade de vida, preservação do meio ambiente, melhoria de renda familiar e afixação do homem no meio rural.

Diante disso podemos verificar que a apicultura tem se apresentado como uma alternativa econômica para os pequenos produtores, agregando valor às propriedades. A produção de mel no estado do Rio Grande do Norte teve um aumento relativo a $1000 \%$ nos últimos dez anos. Ao longo desses anos o governo do estado investiu na produção do mel em comunidades rurais, através de projetos e programas sociais de inserção do 
homem no campo. Hoje o setor de apicultura no estado potiguar é responsável por cerca de 20 mil empregos diretos. (ASSESSORIA E COMUNICAÇÃO, 2009) ${ }^{10}$.

$\mathrm{O}$ governo do RN vem realizando alguns investimentos no setor apicultor do estado como, por exemplo, a concessão de incentivos fiscais, capacitação, assistência técnica, instalação de novos apiários para os pequenos produtores, incremento tecnológico e o Programa Desenvolvimento Solidário. Através desse programa 3.268 famílias rurais foram beneficiadas com recursos para implantação de projetos de apicultura, entre 2004 e 2007. (ASSESSORIA E COMUNICAÇÃO, 2009).

Foi inaugurado na cidade de Mossoró, o Centro de Tecnologia de Apicultura e Meliponicultura do RN (CETEC). A unidade de estudos e desenvolvimento da cultura apícola oferece aos produtores suporte técnico para elevar a produção e a qualidade do mel e seus derivados. Em funcionamento também na cidade de Mossoró o Entreposto de Mel Brasil, com capacidade para beneficiar 2.000 toneladas ao mês e responsável pela geração de novas possibilidades de renda para quem explora a atividade. Em 2007, o Rio Grande do Norte ganhou também a maior fábrica de beneficiamento de mel da América Latina, com capacidade de processar $40 \mathrm{mil} \mathrm{kg}$ por dia. (ASSESSORIA E COMUNICAÇÃO, 2009)

Diante de todos esses aspectos, teóricos e metodológicos iremos analisar o estudo de caso feito na cooperativa COOPAPI, em Apodi para que possamos analisar todo aspecto teórico estudado e verificar como esse processo de gestão é inserido e ocorre na realidade dessa associação.

\section{ASPECTOS INSTITUCIONAIS DA COOPAPI}

A cooperativa estudada, COOPAPI surgiu no ano de 2004 no municio de Apodi no estado do Rio Grande do Norte. A idéia de produzir mel partiu de um produtor da região do Apodi, onde então surgiram algumas associações interessadas na área apícola. $\mathrm{O}$ surgimento da cooperativa se deu, pela necessidade de comercialização do mel, ou seja, na época havia três diferentes associações, datada desde 1991, e a maior dificuldade que as associações encontravam era na hora da venda, pois, cada associação vendia seu produto com valor final diferente.

Diante dessa inquietação surgiu à idéia por parte das associações de se unificar e formar uma cooperativa. Em busca de orientação contatarão o (SEBRAE), o órgão resolveu realizar um fórum de apicultura, com o objetivo de capacitar e formar essa nova organização. A capacitação começou com 30 associados e seu termino se deu com apenas 22 pessoas. Mais já ao final do ano de 2004, a cooperativa terminou com um registrado de 50 associados.

Hoje a cooperativa conta com 208 famílias e um cadastro de reserva de mais 100 produtores. A presidente afirma que ainda não há uma estrutura para adicionar todas essas famílias ao corpo da organização, mais deixa claro que pretende expandir e inserir aos poucos cada vez mais famílias dentro da cooperativa.

\footnotetext{
${ }^{10}$ A ASSECOM: assessoria em comunicação ltda. Portal de comunicação, no estado do Rio Grande do Norte ver: http://www.assecom.com.br/.
} 
A única exigência para fazer parte da cooperativa e que o cooperado seja agricultor familiar. A entrevistada também identifica que apenas de 3 a $4 \%$ dos cooperados não são cadastrados como agricultores familiares, mas possui algum vínculo com cooperado que faz parte dessa exigência, ou seja, é um filho de agricultor é nascido na região.

Não há um período probatório para inserção de novos associados e quem aprova a entrada dos mesmos é a própria diretoria através de preenchimento de um cadastro.

A direção da cooperativa é formada por: uma presidente, seguida por um vice, um tesoureiro, segundo tesoureiro, um secretário e um segundo secretário. Podemos observar que a gestão da cooperativa é totalmente descentralizada, pois as decisões sobre todos os aspectos administrativos são tomadas por todos os componentes da gestão, ou seja, uma vez por semana há reuniões entre a administração da cooperativa para que juntos possam tomar as decisões referentes à organização.

E quanto à direção da cooperativa, há dois registros bastante interessantes a se destacar, o primeiro é que a cooperativa é gerida por uma presidente, ou seja, é uma mulher quem esta a frente de todos os aspectos organizacionais, e o segundo registro é que todos que fazem parte da gestão ou trabalham na direção da cooperativa são: associados ou filhos dos mesmos, pois a presidente afirma que "não seria viável que o cooperado pagasse um funcionário para tomar conta de sua propriedade, para que ele trabalhe na organização para ganhar apenas um salário mínimo", pois é este o valor paga a todos que trabalham na administração da cooperativa.

\section{ATIVIDADES PRODUTIVAS AGRÍCOLAS}

No que tange aos aspectos produtivos e agrícolas, podemos destacar que no período de 2004 a 2007 a cooperativa só trabalhava com a cultura do mel, a partir de 2008 é que surgi o interesse de trabalhar com castanha de caju e seus derivados como: farinha de castanha, farinha de fubá, castanha caramelizada. Então a cooperativa também decidiu apoiar outras culturas como a produção de doces, o artesanato, o algodão orgânico, a polpa de fruta entre outros.

Diante disso havia um empecilho, pois, quando a cooperativa foi fundada em 2004 foi feito um estatuto junto ao (SEBRAE), apenas para o cultivo de mel, a partir do momento que foi realizada a primeira comercialização de mel, a cooperativa resolveu expandir e reformular o estatuto, para que outros produtos fossem inseridos e comercializados pela cooperativa, ou seja, o estatuto foi reformulado para que a cooperativa pudesse trabalhar com mel e produtos derivados da agricultura familiar.

Com relação ao tamanho médio das propriedades dos cooperados, estes variam de 10 a 50 hectares, no geral a média equivale de 25 a 30 hectares, e a média de volume de mel produzido e de 300 mil toneladas ao ano.

No âmbito referente aos principais consumidores dos produtos da COOPAPI, podemos destacar: o governo do estado, supermercados, pequenos comerciantes e parte da produção é viabilizada para exportação, ou seja, geralmente durante o ano a cooperativa envia um contêiner para os Estados Unidos. Para essa exportação e necessário que o mel seja beneficiado em Mossoró, pois, é nessa cidade que foi inaugurado um entreposto de 
mel, para que os agricultores possam ter uma melhor idéia quanto ao preço e mercado do produto, servindo de orientação para a cooperativa.

No momento a cooperativa só exporta um contêiner, pois, para que essa demanda ocorra e necessário que haja uma mobilização de dois a quatro meses de acúmulo na produção de mel. Como não compensa deixar o capital parado durante tanto tempo é necessário que haja uma compra de grande volume da produção, para que possa ocorrer essa transação.

Não há diferenciação quanto à qualidade do mel para comercialização seja aqui no Brasil ou para exportação, a única diferença referente a exigência para exportação é quanto à cor do produto, ou seja, quanto mais claro para os americanos e europeus melhor.

Quanto aos produtos da cooperativa estes possuem marca própria chamada de "mel potiguar- produtos terra firme", uma curiosidade a ser mencionada e quanto ao nome escolhido pela cooperativa, pois, "terra firme" significa Apodi, esse nome foi dado pelos índios na época que chegaram à cidade. A associação possui um site para que seus clientes possam manter contato e tirar algumas dúvidas a respeito da cooperativa.

No âmbito dos projetos da cooperativa podemos destacar: a conclusão de uma indústria de mel no próprio município, que já esta em processo de construção, essa indústria esta sendo construída através da secretaria de agricultura, e outro projeto é a unidade de padronização financiada pela fundação Banco do Brasil. A associação também esta concorrendo ao projeto campo forte, projeto esse desenvolvido através do governo do estado, onde estão buscando recursos como um carro "F 4000", 1000 baldes para depositar o mel bruto, 200 tambores e uma empilhadeira.

Com relação aos projetos realizados através de recursos próprios da cooperativa, os principais são a reforma de uma lojinha ao lado da sede, na zona urbana para melhor expor seus produtos, buscam a compra de um carro para viabilizar o manejo da produção e a reforma do próprio escritório da sede.

\section{ASPECTOS TÉCNICOS}

Fazendo menção aos aspectos técnicos da COOPAPI, podemos destacar que todos os equipamentos utilizados são de propriedade da própria cooperativa como também o local de funcionamento.

Vale salientar que a sede da cooperativa esta situada na área urbana, local este que os cooperados deixam o mel ainda bruto, dentro das baldes para que eles sejam armazenados e depois sejam enviados para zona rural, onde existe outro galpão para que o mel seja beneficiado. Trabalham no processo de beneficiamento do mel em sache nove cooperados, divididos em dois turnos, cinco pessoas durante o dia e quatro a noite.

O processo de beneficiamento começa quando o mel é recebido no deposito na área rural este mel é recebidos dentro dos baldes, colocados no depósito chamado (decantador), que serve para que o mel fique em repouso durante três dias, e assim seja retirado algum tipo de resido existente, depois é retirado do depósito e colocado numa 
espécie de almogenizador. Em seguida é misturado no intuito de ficar com apenas uma coloração, depois é aquecido para que se torne mais fino, onde já sai coado e filtrado e vai para um deposito onde é impulsionado por uma espécie de compressor que impulsiona o mel para uma mangueira para ser embalado dentro dos saches.

Depois de beneficiado os saches são lavados e postos para secar, só então são embalados e selados para serem condicionados dentro das caixas. Depois desse processo de beneficiamento, o mel volta para a sede da cooperativa onde é comercializado e distribuído.

Quanto ao aspecto de manutenção dos equipamentos, podemos considerar que esta é preventiva, no que diz respeito ao mel, é o próprio distribuidor que faz a manutenção, já no que diz respeito ao maquinário da castanha, são os próprios cooperados que fazem a manutenção, ou vem à assistência especializada contratada por um técnico a parte.

O processo produtivo é considerado artesanal desde criação dos apiários até o beneficiamento. Os meios de divulgação para venda dos produtos são: exposições, feiras, rodadas de negócios e programas do governo como é caso do Programa de Aquisição de Alimentos (PAA), programa governamental de estímulo ao consumo interno, que objetiva a compra da produção da agricultura familiar.

A cooperativa participa dele vendendo para a merenda escolar seus produtos, como: mel, castanha e outros. No início foi difícil a inserção do mel no programa, por ser considerado um produto de sobremesa, não principal como o feijão e o arroz. Depois a dificuldade de inserir a castanha no projeto, onde a cooperativa contou com o apoio de uma nutricionista, que justificou cientificamente a importância da inclusão da castanha na merenda escolar.

Outro importante passo dado pela cooperativa foi à inclusão de seus produtos em um supermercado da capital, o Bom Preço, que através de um vendedor porta a porta conseguiu essa parceria, para que a cooperativa possa vender seus produtos. Quanto ao prazo de entrega dos produtos, verifica-se que ocorre sem nenhum tipo de atraso ou nenhuma dificuldade logística, sendo o transporte da produção feita através de um caminhão.

Existe na cooperativa capacitação para os associados, uma delas é com o Ministério do Desenvolvimento Agrário (MDA) no qual um engenheiro agrônomo vai até as propriedades dos cooperados prestar assistência técnica e orientar os produtores como, por exemplo, o manejo com os cajueiros. Mais ainda verifica-se certa carência quanto a esse aspecto técnico.

\section{ASPECTOS ORGANIZACIONAIS E DE GESTÃO}

Quanto aos aspectos organizacionais podemos começar falando sobre a direção da cooperativa, no que diz respeito à presidente da cooperativa esta está na administração da mesma, desde o início da implementação, assumindo a direção no final do ano de 2005, quando o primeiro presidente resolveu sair da direção para se dedicar totalmente a sua propriedade. O tempo de duração do conselho administrativo vária de três em três anos, estando à atual gestora no seu segundo mandato. A reunião do conselho 
administrativo acontece semanalmente e os registros são feitos através de atas colocados no mural da sede da cooperativa. Como também a prestação de contas que é feita semanalmente é fixada no mural.

A pauta das reuniões e assembléias é elaborada por todos os componentes da gestão e é sempre lida antes do início das mesmas, os principais assuntos discutidos abrange todos os assuntos da cooperativa como: gestão, financeiro, dificuldades, problemas e soluções em geral. Sendo divulgadas através de cartazes fixados na cooperativa e pela comunicação pessoal, ou seja, através da divulgação dos próprios associados.

As decisões tomadas nas assembléias ou reuniões são divulgadas por meio de atas e conversa informal, um aspecto bastante inovador é que, a cooperativa tem um programa na rádio da cidade que acontece semanalmente toda terça- feira as $11 \mathrm{~h} 00 \mathrm{~min}$ da manhã, que serve de meio de divulgação não só para os associados mais para toda a comunidade em geral.

O sistema de punição adotado pela cooperativa é de dar prioridade aos cooperados, quanto aos recursos financeiros, ou seja, adiantamento em dinheiro quanto à produção de mel para aqueles que participaram da assembléia. Já aqueles que não estavam presentes nas reuniões, não dispõem dessa vantagem de imediato.

Quanto ao planejamento anual da cooperativa, este é feito por todos os associados em meio às assembléias, geralmente nos meses de janeiro ou fevereiro, estando à organização com um plano de negócios elaborados até o ano de 2012. Daí, identificamos quanto à cooperativa se encontra organizada. No que diz respeito ao conselho fiscal, esse é renovado a cada dois anos e é escolhido também durante as assembléias.

A cooperativa possui várias parcerias a ser destacada com grande importância nacional, como é o caso da Fundação Banco do Brasil, Serviço Brasileiro de Apoio às Micros e Pequenas Empresas (SEBRAE), Ministério do Desenvolvimento Agrário (MDA), Companhia Nacional de Abastecimento (CONAB), Instituto de Desenvolvimento Sustentável (IDS), Empresa de Pesquisa Agropecuária do Rio Grande do Norte (EMPARN) e a Empresa de Assistência Técnica e Extensão Rural (EMATER). Possui também uma parceria com a prefeitura de Apodi buscando melhoria na qualidade bucal de seus associados, promovendo semanalmente a visita de um dentista na zona de beneficiamento do mel, que fica a dez quilômetros da cidade.

A organização também se destaca por estimular a educação entre seus cooperados, ou seja, incentivando a educação básica, promovendo parceira com universidade Estadual do Rio Grande do Norte (UERN), com um curso de formação política, promovido para os filhos dos cooperados. Outra parceria é com o Projovem do Campo- Saberes da Terra, onde foi formada uma turma no ano de 2009 no fórum de educação do Campo e incentivando também os membros da direção a se profissionalizar no ensino superior, dando incentivos como: redução da carga horária, trabalhar na área na qual esta se formando, entre outros.

A cooperativa também promove programas de educação ambiental com palestra, seminários, não utilizando agrotóxico no processo de apicultura ou em nenhuma outra cultura. 
Quanto às dificuldades da gestão cooperativista a presidente destaca que, a maior delas é a falta de reconhecimento pelo trabalho feito na cooperativa, às vezes os cooperados não compreende, por exemplo, que ela tem que se ausentar e fazer algumas viagens buscando mais subsídios para a cooperativa, essa desconfiança surge e ela tem que explicar com detalhes que viajem e feita atreves de parceiras com alguns órgãos públicos e não com o dinheiro da cooperativa.

Outra dificuldade que ela destaca é a falta de apoio por parte dos órgãos públicos, ela tem que batalhar muito para conseguir apoio junto à prefeitura e até mesmo apoio do governo do estado, com relação há incentivo na produção, na logística entre outros.

Outro fator que a presidente da COOPAPI Destaca é que a cooperativa precisa de mais apoio ao crédito junto aos bancos, ela sente um pouco de dificuldade quanto a esse aspecto. E também de lidar com o numero tão grande de associados, são 208 famílias que na voz dela "precisa sempre concorda com o associado, como se ele fosse uma espécie de cliente, que sempre tem razão, mostrando detalhadamente todas as receitas e despesas para que não haja nenhuma espécie de desconfiança ou descredibilidade".

\section{ASPECTOS ECONÔMICOS}

Fazendo uma breve abordagem quanto aos aspectos econômicos da cooperativa, podemos destacar que a COOPAPI possui um fundo de reserva e também o Fundo de Assistência Técnica Educacional e Social (FATES), além de capital social e cotas partes.

No que tange a Lei 5764/71 referente aos fundos existentes nas cooperativas podemos destacar o artigo 28, referente ao fundo de reserva da cooperativa onde:

Art. 28. As cooperativas são obrigadas a constituir:

I - Fundo de Reserva destinado a reparar perdas e atender ao

desenvolvimento de suas atividades, constituído com 10\% (dez por cento),

pelo menos, das sobras líquidas do exercício;

II - Fundo de Assistência Técnica, Educacional e Social, destinado a prestação de assistência aos associados, seus familiares e, quando previsto nos estatutos, aos empregados da cooperativa, constituído de $5 \%$ (cinco por cento), pelo menos, das sobras líquidas apuradas no exercício.

A organização conta com credito público da Companhia Nacional de Abastecimento (CONAB), de fornecedores, clientes e dos chamados trading ${ }^{11}$ Possui também acesso ao crédito junto ao Banco do Nordeste.

Fazendo um balanço anual referente a 2009 o saldo da cooperativa foi positivo, havendo sobras de 120 mil reais, ou seja, parte distribuída para os cooperados, parte investido na cooperativa. No que se refere aos anos anteriores podemos destacar várias benfeitorias feitas na cooperativa, em 2006 foi feito um investimento nas embalagens dos saches dos melzinhos, em 2007 ampliações e reforma da sede da cooperativa e em 2008 devido ao aumento da comercialização do mel parte das sobras foi distribuído entre os cooperados.

\footnotetext{
${ }^{11}$ Trading é uma empresa especializada em intermediar operações comerciais de exportação e importação para os mais diferentes segmentos de mercado.
} 
Vale salientar que desde a fundação da cooperativa em 2004 até 2008 foi registrado sempre um superávit nas contas da COOPAPI.

Por fim a contabilidade é realizada por um contador contratado, feita através de um registro num banco de dados na cooperativa e repassado para o mesmo.

\section{CONSIDERAÇÕES FINAIS}

A presente pesquisa permitiu-nos constatar a importância da apicultura na região do Apodi e verificar que não só a cultura do mel, principal foco desse trabalho, mas, outras atividades da agricultura familiar como: castanha de caju, algodão orgânico entre outros cultivos estão servindo para melhorar o desenvolvimento social e econômico dessa população. Sem contar a potencialidade

Os resultados indicam que os esforços e as estratégias adotadas pela gestão da cooperativa COOPAPI estão no caminho correto, pois, segundo Oliveira (2006), os principais problemas identificados na gestão das cooperativas são: a falta ou o esquecimento da educação cooperativista e a aplicação de modelos de gestão centralizados, inadequados e desatualizados.

Como se pode verificar a COOPAPI, adota vários aspectos de gestão e autogestão, sem esquecer os princípios cooperativistas, graças à adoção de um modelo de gestão descentralizado que conta com a participação e a colaboração de todos os cooperados. Pode-se chagar a essa conclusão, pois, a presidente afirma que as pautas das reuniões são discutidas junto com todo o corpo administrativo, repassado para os cooperados e por fim acata as sugestões dos mesmos, que serão utilizadas em vários setores da cooperativa.

No processo de construção educacional a cooperativa incentiva seus colaboradores fazendo com que estes se profissionalizem, aprendendo novas estratégias e trazendo inovações para o setor cooperativista. Buscando parcerias através de palestras, sobre cooperativismo, políticas entre outras a COOPAPI incentiva também a educação do ensino básico até o superior. Minimizando assim os problemas que oliveira aponta tanto na gestão quanto na educação cooperativista. Isso nos leva a crer que a COOPAPI cumpre um papel solidário com seus cooperados.

Podemos dizer que a cooperativa tem adotado estratégias inovadoras, uma delas se da através de um programa de transparência que a cooperativa possui na rádio local, podendo divulgar suas atuações, não só para seus cooperados mais para toda comunidade apodiense, reuniões periódicas para demonstrar resultados entre outros. Facilitando assim a comunicação entre os associados. Outro aspecto inovador bastante relevante é que a cooperativa possui um plano de negócios até 2012, delimitando as metas para desenvolver melhor seu trabalho.

Como nem todos os resultados são positivos, nem na cooperativa ou em qualquer tipo de organização, a associação passa por dificuldades quanto aos aspectos técnicos afirmando a presidente e a secretaria da cooperativa que, necessitam de mais orientação e assistência técnica. 
Sendo assim, podemos destacar que a pesquisadora conseguiu fazer a ligação quanto ao aposto teórico, na realidade dessa cooperativa, apesar do pouco tempo existente para fazer a pesquisa. Ainda assim, ah muito a ser pesquisado para que esse estudo ganhe mais eficácia no desenvolvimento da gestão e possa ser utilizado por outros empreendimentos.

Nesse processo de construção permanente, os avanços e recuos da COOPAPI se descrevem como fonte permanente do interesse de toda a sociedade, orientado a continuidade de investigação.

\section{REFERÊNCIAS}

1. ANUÁRIO DO COOPERATIVISMO BRASILEIRO. Brasília: OCB, 2000.

$2 . \quad$ Brasília: OCB, 2003.

3. ASSOCIAÇÃO BRASILEIRA DE CONSULTORIA E ASSESSORIA EM COMÉRCIO EXTERIOR. Exportação de mel cresce $92 \%$ em março e preço bate recorde. ANS, 29 de abril de 2010. Disponível em: <http://www2.abracomex.org/index.php? getx=noticias\&intId=188> acesso em: 17 jun. 2010.

4. ABRANTES, José. Associativismo e cooperativismo: como a união de pequenos empreendedores pode gerar emprego e renda no Brasil. Rio de janeiro: Interciência, 2004.

5. AGÊNCIA SEBRAE. Exportação de mel cresce $92 \%$ em março e preço bate recorde. Disponível em: <http://www.canalrural.com.br/canalrural/jsp/default.jsp?uf=sc\&local=1\&id= 2885915\&action=noticias $>$ acesso em: 13 jun. 2010.

6. ALICEWEB. Exportação de mel natural do RIO GRANDE DO NORTE em 2009 Via: MARITIMA. Disponível em: < http://aliceweb.desenvolvimento.gov.br/consulta_nova/ resultadoConsulta.asp> acesso em: 14 jun. 2010.

7. ARRUDA, Carlos Alberto; GOULART, Linda; BRASIL, Haroldo Vinagre. Estratégias de internacionalização: competitividade e incrementalismo. In: ENANPAD, Encontro Nacional da Associação Nacional dos Programas de Pósgraduação em Administração, XVIII, 1994. Atibaia.

8. ASSESSORIA E COMUNICAÇÃO. Exportação de Mel. Disponível em: $<$ http://www.assecom.rn.gov.br/notAnt.asp?idnoticia=3446> Acesso em: 10 dez.2009.

9. BENATO, João Vitorino Azolin. O ABC do cooperativismo. 5 ed. São Paulo: Ocesp, 1999.

10. BARNARD, Chester. As funções do executivo. São Paulo: Atlas, 1979.

11. BULGARELLI, Waldirio. As sociedades cooperativas e sua disciplina jurídica. 2 ed. Rio de Janeiro: Renovar, 2000.

12. CANÇADO, Airton Cardoso. Autogestão em cooperativas populares: os desafios da prática. Salvador: IES, 2007. 
13. CANÇADO, Airton Cardoso; PEREIRA, José Roberto; SILVA, Jeová Torres Júnior. Economia solidária, cooperativismo popular e autogestão: as experiências de Palmas- TO. Palmas, TO: NESOl; UFT, 2007.

14. CARRADORE, Enir Antonio. Sociedades cooperativas e imposto sobre a renda. Florianópolis: $\mathrm{OAB} / \mathrm{SC}, 2005$.

15. CAVALCANTI, M. (Org). Gestão Social, estratégias e parcerias: redescobrindo a essência da administração brasileira de comunidades para o terceiro setor. São Paulo: Saraiva, 2006.

16. GIL, Antonio Carlos. Como Elaborar Projetos de Pesquisa. 4 ed. São Paulo: Atlas, 2002.

17. CHIAVENATO, Idalberto. Introdução à Teoria Geral da Administração. 4. ed. São Paulo: Makron, 1993. ed. Rio de Janeiro: Campus, 2000. . Introdução à teoria geral da administração. 6.

19. EMPRESA BRASILEIRA DE PESQUISA AGROPECUARIA. Agricultura Familiar. Disponível em: <http://www.embrapa.br/imprensa/artigos/2002/artigo. 2004-12-07.2590963189/> Acesso em: 24 nov. 2009.

20. FERREIRA, Ademir Antonio; REIS, Ana Carla Fonseca; PEREIRA, Maria Isabel. Gestão Empresarial: de Taylor aos nossos dias: evolução e tendências da moderna administração de empresas. São Paulo: Pioneira. Thomson Learning, 1997.

21. FIGUEREDO, Ronise de Magalhães. Dicionário prático de cooperativismo. Belo Horizonte: Melhoramentos, 2000.

22. JOYEUX, M. Autogestão, gestão direta, gestão operária. Brasília: Novos Tempos, 1998.

23. MAIA, Jayme de Mariz. Economia Internacional e Comércio Exterior. 8 ed. São Paulo: Atlas, 2003.

24. BRASIL. MINISTERIO DO TRABALHO E EMPREGO. Agricultura Familiar. Disponível em: <http://www.mte.gov.br/geral/busca/buscaGeral.asp>. Acesso em: 24 nov. 2009.

25. LUZ FILHO, Fabio. Teoria e prática das sociedades cooperativistas. 5 ed. Rio de Janeiro: Pongetti, 1961.

26. NATALPRESS. Exportação de Mel. Disponível em: $<$ http://www.natalpress.com/index. php?Fa=mat.inf\&EDI_ID=5\&MAT_ID=23905> Acesso em: 10 dez. 2009.

27. OLIVEIRA, Djalma de Pinho Rebouças de. Manual de gestão das cooperativas: uma abordagem prática. São Paulo: Atlas, 2001.

28. . Manual de gestão das cooperativas: uma abordagem prática. 3 ed.São Paulo: Atlas, 2006.

29. ORGANIZAÇAO DAS COOPERATIVS BRASILEIRAS. Manual de orientação para constituição e registro de cooperativas. Brasília: SESCOOP, 2003. 
30.

Evolução do Cooperativismo. Disponível em:

<http://www.ocb.org.br/site/cooperativismo/evolucao_no_brasil> Acesso em: 24 nov. 2009.

31. PERFEITO, Giovana. APICULTURA: Exportação brasileira de mel cresce quase 12\% em março. Agencia SEBRAE 24 de Abril de 2009. Disponível em: $<$ http://www.global21.com.br/materias/materia.asp?cod=24468\&tipo=noticia $>$ acesso em: 17 jun. 2010.

32. PINHO, D. B. A doutrina cooperativa nos regimes capitalista e socialista. 2. ed. São Paulo: Pioneira, 1966.

33. PINHO, Diva Benevide. Manual de cooperativismo, volume 1: O pensamento cooperativo e o cooperativismo brasileiro. II triagem, CNPq 1982.

34. PIRES, Maria Luiza Lins e Silva et al. Cenários e tendências do cooperativismo brasileiro. Recife: Bagaço, 2004.

35. PORTAL DE INVESTIMENTO E INFORMAÇÃO. Exportação de Mel. Disponível em: <http://www.investne.com.br/Noticias-Rio-Grande-do-Norte/riogrande-do-norte-planeja-exportar-mel-para-a-europa> Acesso em: 10 dez 2009.

36. PORTAL DO COOPERATIVISMO. Estrutura do Cooperativismo. Disponível em:

$<$ http://www.portaldocooperativismo.org.br/sescoop/cooperativismo/estrutura_co operativismo.asp> Acesso em: 24 nov. 2009.

37. POLONIO, Wilson Alves. Manual das sociedades cooperativas. 4. ed. São Paulo: Atlas, 2004.

38. PEREIRA, F. M. et al. Produção de mel. Ministério da Agricultura, Pecuária e Abastecimento, Embrapa Meio- Norte, Sistema de Produção, jul. 2003.

Disponível em <http:/sistemasdeprodução.cntia.embrapa.br> acesso 15 nov. 2009.

39. RIO GRANDE DO NORTE. GOVERNO DO ESTADO. Desenvolvimento apicultor. Disponível em:

<http://www.rn.gov.br/contentproducao/aplicacao/govrn/imprensa/ enviados/noticia _detalhe.asp?nCodigoNoticia=11181> Acesso em: 11 dez. 2009.

40. SANTOS, Sivaldo Ramos. Agricultura Familiar no Brasil. Webartigos.

Publicado 12/01/2010

Disponível: $<$ http://www.webartigos.com/articles/31006/1/Agricultura-Familiar-no Brasil/pagina1.html\#ixzz0upPoQixA> Acesso em 15 jun. 2010.

41. SEBRAE- NA. Exportações de mel em alta e com preço recorde. Disponível em: $\quad<$ http://www.sebrae.com.br/setor/apicultura/sobreapicultura/mercado/exportacoes $>$ acesso em: 15 jun. 2010.

42. SILVA FILHO, Cícero Virgulino. Cooperativas de Trabalho. São Paulo: Atlas, 2001.

43. SILVA NETO, P. Q. da et al. Cooperativismo como organismo equalizador da renda. In:

44. EGEPE - ENCONTRO DE ESTUDOS SOBRE EMPREENDEDORISMO E GESTÃO DE 
45. PEQUENAS EMPRESAS. 1., 2000, Maringá. Anais... Maringá: UEM/UEL, 2000.

46. SINGER, Paul. Autogestão e socialismo: oito hipóteses sobre a implantação do socialismo via autogestão. In: DEMOCRACIA e autogestão, publicação especial TEMPORAES, São Paulo: Humanitas Publicações FFLCH/USP, 1999.

47.

. Economia Solidária: um modo de produção e distribuição. In: SINGER, P.; SOUZA, André Ricardo de. A Economia Solidária no Brasil. São Paulo: Contexto, 2000.

48. SINGER, Paul (Org.). Uma outra economia é possível. São Paulo: Contexto, 2003.

49. STORCH, S. Uma perspectiva estrutural sobre cooperativas industriais. In: MOTTA, Fernando C. Prestes et al. Participação e participações: ensaios sobre autogestão. São Paulo, Babel Cultural, 1987.

50. TACHIZAWA, Takeshy ; REZENDE, Wilson. Estratégia: tendências e desafiosum enfoque na realidade brasileira. São Paulo: Makron Books, 2000.

51. TAUILE, José Ricardo et al. Empreendimentos autogestionários provenientes de massas falidas: relatório final: junho de 2004. Brasília: MTE, IPEA, ANPEC, SENAES, 2005.

52. TAVARES, Mauro Calixta. Gestão Estratégica. 2. Ed. 3. Reimpr. São Paulo: Atlas, 2007.

53. TEDESCO, Wanderley (Org.). Raízes históricas do campesinato brasileiro. Agricultura familiar: realidades e perspectivas. Passo Fundo, RS: UPF, 2001.

54. TREVISAN, M. D. P.; TREVISAN, M.; VIDAL, R.. Os produtos das Abelhas. Barretos: Faculdade de Ciências de Barretos, 1981.

55. UOL. Exportação de mel. Disponível em: <http://cosmo.uol.com.br/noticia/35912/2009-08-24/exportacoes-de-mel-jasuperam-as-cifras-de-2008.html> Acesso em: 03 dez. 2009.

56. VEIGA, Sandra Mayrink; FONSECA, Isaque. Cooperativismo: uma revolução pacífica em ação. Rio de Janeiro: DP\&A: Fase, 2001.

57. VERGARA, Sylvia Constant. Projetos e relatórios de pesquisa em administração. 9 ed. São Paulo: Atlas, 2007. 
APÊNDICE A

QUESTIONÁRIO APLICADO NA COOPERATIVA COOPAPI.

1- IDENTIFICAÇÃO

DADOS CADASTRAIS DO EMPREENDIMENTO

Nome ou Razão Social:

Atividade Econômica:

Endereço: $\mathbf{n}^{\mathbf{o}}$

Bairro/comunidade:

CEP:

Telefone:

Email:

\section{IDENTIFICAÇÃO DO (A) ENTREVISTADO (A)}

Nome: idade:

Endereço: $\mathbf{n}^{\circ}$

Bairro/comunidade:

CEP:

Telefone:

Email:

Cargo ou função no empreendimento:

Tempo de admissão no empreendimento:

\section{HISTÓRICO DA COOPAPI}

\section{ASPECTOS INSTITUCIONAIS}

1. Como surgiu a cooperativa, quais as razões que colaboraram para implementá-la?

2. De quem foi à idéia?

3. Como foi a participação dos envolvidos?

4. A cooperativa começou com quantas pessoas?

5. Quantas pessoas possuem atualmente?

6. Quantas mulheres são associadas?

7. Quantos homens são associados? 
8. Quais os pré-requisitos para ingressar na organização?

() parentesco () objeto social () indicação () amizade () indicação política () critérios técnicos

9. Há um período probatório para os novos associados?

10. Quem aprova a entrada de novos membros?

11. Quantas pessoas fazem parte da direção da cooperativa?

\section{ASPECTOS TÉCNICOS}

12. Os equipamentos do empreendimento são:

() próprios () alugados () emprestados () doados () não possuem () não sabe responder

13. O local de funcionamento do empreendimento (sede) é:

() própria () alugada () emprestada () doada () não possui () não sabe responder

14. Há manutenção preventiva? () sim () não

15. A manutenção é feita: () pelos associados () por terceiros

16. Processo de produção: () manual () artesanal () industrial

17. Quanto ao cumprimento do prazo de entrega dos produtos/serviços

() sempre ocorre () eventualmente ocorre () raramente ocorre () nunca ocorre

18. Quais os meios utilizados para vender os produtos ou serviços (feiras, porta-porta etc.)?

19.

20. O empreendimento compra algum produto em parceria com outro empreendimento?

() Sim () Não. Quais?

\section{ATIVIDADES PRODUTIVAS AGRÍCOLAS}

21. Quais são os projetos da cooperativa?

22. De onde surgiu a idéia de produzir mel? O que motivou tal escolha?

23. Além da produção de mel existem outras culturas?

24. Quais os mecanismos utilizados pela cooperativa para garantir a qualidade da produção?

25. Qual é o tamanho médio das propriedades dos cooperados?

26. Qual a área média e o volume da produção de mel? 
27. Como é feita a comercialização da produção do mel? Há algum intermediário ou é direto ao consumidor?

28. Como é feito o transporte da produção de mel?

29. Quem são os principais consumidores do mel produzido pela COOPAPI?

30. Há algum processo de seleção dos produtos? Para comercialização nacional/ internacional?

31. Qual a origem do mel? Toda produção e fornecida pelos próprios produtores? Ou tem alguma parte advinda de fora da cooperativa?

32. Há assistência Técnica? É freqüente ou esporádica? Quem presta o serviço?

33. Há algum técnico disponibilizado pela cooperativa para acompanhar as propriedades?

34. O acompanhamento técnico é executado durante todo o ciclo produtivo ou em parte deste?

35. Como é a infra-estrutura disponível para a produção? Há espaço de produção coletiva entre os cooperados? (galpões)

36. A produção é suficiente para atender as demandas?

37. Os produtos possuem marca própria?

\section{ASPECTOS ORGANIZACIONAIS E DE GESTÃO}

38. Quanto tempo faz que você esta na gestão da cooperativa?

39. Como é que você administra à cooperativa?

40. Qual foi a maior dificuldade encontrada em sua gestão? Se houver, como foi resolvido?

41. Qual o tempo de duração do Conselho Administrativo?

() 1 ano () 2 anos () 4 anos () não há um tempo definido

42. Há reuniões mensais para o Conselho Administrativo (em torno de quantas)?

43. Como é feito os registros das reuniões?

44. Qual a pauta da última reunião/ Assembléia?

45. Quem elabora a pauta das reuniões/assembléias?

46. A pauta das reuniões é lida antes do início da mesma? 
47. () sim () não () às vezes () a pauta é sempre montada na hora

48. Como são divulgadas as pautas das reuniões? ( ) e-mail ( ) pessoal/comunicação face-face () cartazes na sede da cooperativa

49. Como são divulgadas as decisões tomadas em Assembléias/reuniões:

() por meio de Atas () relatórios () anotações informais () conversa informal () não há um critério estabelecido

50. Geralmente quais os principais assuntos discutidos nas reuniões e assembléias?

51. Existe prestação de contas

( ) mensal ( ) semanal ( ) bimestral ( ) anual ( ) não existe uma freqüência bem definida

52. Qual o principal veículo de comunicação utilizado para divulgar informações aos associados:

() rádio comunitária () jornal () TV ( ) e-mail ( ) pessoal/comunicação face-face

53. A cooperativa possui alguma punição para os que não participam das assembléias e reuniões?

54. Há capacitação? Em que horário ocorrem às mesmas?

() fora do horário de trabalho () durante o horário de trabalho () não há capacitações

55. As capacitações são contabilizadas como dia de serviço?

56. Vocês têm um planejamento anual? Se sim já elaboraram o planejamento institucional de 2011?

57. Geralmente participam no planejamento das atividades:

58. () somente a administração () todos os associados

59. Qual a porcentagem de participação:

a) Reuniões

b) Capacitações

c) Assembléias

d) A cooperativa possui parcerias? Qual (is)?

60. Há conselho fiscal?

61. Qual a frequiência de reuniões do conselho Fiscal?

() semanal () mensal () quinzenal () bimestral () trimestral () anual () quando há necessidade

62. A cooperativa estimula a educação básica, ensino médio e superior (supletivo e regular) dos associados?

() Sim () Não.

63. De que maneira. 
64. A cooperativa busca melhorias das condições de saúde e segurança dos trabalhadores?

() Sim () Não

65. De que maneira.

66. A cooperativa possui algum programa de Educação Ambiental

67. Como é feita a renovação da gestão da cooperativa (Conselho Administrativo e Conselho Fiscal)

\section{ASPECTOS ECONÔMICOS}

68. Fundos existentes:

() Fundo de Reserva () Fundo de Assistência Técnica Educacional e Social - FATES () outros:

69. A organização conta com crédito:

70. () crédito dos membros () público () fornecedores ou cliente () solidário () não possui crédito

71. Possui acesso a algum crédito? Qual (is)?

72. Há projeto para capitação de crédito para algum tipo de produto?

73. Fazendo um balanço anual referente ao ano de 2009. O saldo da cooperativa foi positivo? Houve sobras?

74. Como são divididas as sobras no final do Exercício Social?

75. Como é feita a contabilidade da cooperativa: por contador ou entre os cooperados? 